\title{
AN INTELlECTUAL HistoRy OF COMPARATIVE TAX LAW
}

\author{
KIM BROOKS
}

In this article, the author argues that comparative tax law has an intellectual history. More specifically, the author claims that history reveals there is a distinguishable comparative tax law scholarship where tax scholars engage in common debates. The author then offers a description of method, highlighting the difficulty of identifying the work that might be considered "comparative tax law." Next, the author conceptualizes and clusters contributions from scholars who have framed the comparative tax law field. The author argues that our national boundedness, combined with the lack of an explicit network of scholars, has masked the rich intellectual history in the field of comparative tax law. Finally, the author concludes by drawing attention to the network effects that seem to inform some of the approaches taken by the key contributors to comparative tax law's intellectual history.

\section{TABLE OF CONTENTS}

I. INTRODUCTION . . . . . . . . . . . . . . . . . . . . . . . . . . . . . . . . . . . . . . . 649

II. Method ............................... 651

III. AN INTELLECTUAL HISTORY OF

COMPARATIVE TAX LAW THEORIES AND METHOdS . . . . . . . . . . . . . 652

A. Phase 1: Planting a Flag in the

DisciplinARY GROUND $(1927-1985) \ldots \ldots \ldots \ldots \ldots \ldots 3$

B. Phase 2: Major Comparative Tax Projects

BY INDIVIDUAL SCHOLARS $(1985-1998) \ldots \ldots \ldots \ldots$. . . . . . . 662

C. Phase 3: Reflective Engagement with the

FUNCTION AND PURPOSE OF COMPARISON

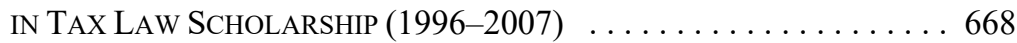

D. Phase 4: Bullding a Community of

Comparative TAX LaW Scholars (2007-2009) . . . . . . . . . . 672

E. Phase 5: Methodological Contest (2009-2016) . . . . . . . 674

F. Phase 6: Reflective Confidence $(2017-) \ldots \ldots \ldots \ldots 78$

IV. OBSERVATIONS ON THE TRAJECTORY OF THE

DisCIPLINE OF COMPARATIVE TAX LAW . . . . . . . . . . . . . . . . . 679

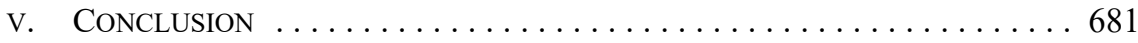

\section{INTRODUCTION}

Intellectual histories render the invisible, visible. In this article, I argue that comparative tax law has an intellectual history: a bold claim. ${ }^{1}$ Nevertheless, as this article demonstrates,

Dean, Faculty of Management, Dalhousie University and the Purdy Crawford Chair in Business Law at the Schulich School of Law. She would like to thank Shane Isler, Kacie Oliver, Okanga Ogbu Okanga, and Emily Wang for their research assistance and participants in the Law and Society seminar series at the University of Toronto, the Tax Policy Colloquium series at McGill University, and Dalhousie's law faculty seminar series for helpful questions and constructive input. Finally, thanks are extended to the Social Sciences and Humanities Research Council of Canada for their support.

1 Among other challenges, "[t]he history of ideas has long been a discipline in disrepute": Arianna Betti \& Hein van den Berg, "Modelling the History of Ideas" (2014) 22:4 British J for History Philosophy 812 at 812 . The claim is also a risky one, given the intensity of the debates about the contours of intellectual, cultural, and social histories and the value of engaging in these kinds of exercises. See e.g. Leslie Butler, 
there is a body of comparative tax law work that builds progressively on related insights and that can be clustered and described in relational ways. In part, the claim of this article is exceptional because unlike areas of tax law where scholars seem to be engaged in a common conversation, in many cases, scholars of comparative tax law appear to write alone. ${ }^{2}$ Many of them do not explicitly respond to, or incorporate, the insights of those who came before them, and even where they do, they do not draw on an extensive body of earlier comparative tax law work. For scholars who adopt a comparative perspective in addressing a particular tax law question or dilemma, the lack of engagement is perhaps understandable: a scholar comparing how Australia, the United Kingdom, and the United States deal with interest deductions might be more interested in the non-comparative work on interest deductibility in those three countries than she is in the comparative tax law scholarship generally or in comparative work on tax avoidance, for example. Why authors fail to acknowledge explicitly the insights of other comparatists, whether of tax law or law more generally, when they author pieces that seek to advance the discipline of comparative tax law (as distinct from efforts to advance an aspect of tax law itself) is less clear.

Nevertheless, the claim of this article is that there is a distinguishable comparative tax law scholarship and that its modern history can be conceptualized in a way that enables it to be coherently told. Although it is often the case that scholars fail to acknowledge the work of those who preceded them, this history reveals that comparative tax scholars engage in common debates. This is perhaps not surprising, despite the fact that some scholars fail to acknowledge earlier contributions. One might predict that in the era of modern technology and travel, the central figures in the intellectual history of comparative tax law know about each other's ideas, even if they are not expressly engaging with one another and indeed, this history reveals the network effect of the relationships among a relatively elite group of tax scholars.

Part II of this article offers a description of method, highlighting the difficulty of identifying the work that might be considered "comparative tax law." Part III is the core of the article. In it, the scholars who have framed the comparative tax law field are identified, and their contributions are conceptualized and clustered. The article generalizes about the ways in which the scholars in each era advanced the field. In reflecting on the comparative tax law contributions of each author in the discipline's intellectual history, the article focuses not on describing their contribution to tax law but rather on their position on major debates in comparative law. So, for example, the countries they choose and their rationale for selecting them is identified, as is their view (if apparent) on whether there is a "common

"From the History of Ideas to Ideas in History" (2012) 9:1 Modern Intellectual History 159; Daniel Wickberg, "Intellectual History vs. the Social History of Intellectuals" (2001) 5:3 Rethinking History 383. Law has not served as a centerpiece at the intellectual history table; nevertheless, for a recent collection, see "Symposium: Opportunities for Law's Intellectual History" (2016) 64:1 Buffalo L Rev 1.

See especially Omri Y Marian, "The Discursive Failure in Comparative Tax Law" (2010) 58:2 Am J Comp L 415 [Marian, "The Discursive Failure"]. This article owes a debt to Marian's earlier work, although the project of this article is distinguished by two features. First, Marian's objective was to bring tax law comparatists into dialogue with each other, in part by aligning them with their comparative law theoretical framework (for example, whether they adopted a functionalist or critical approach). To that end, he explored the work of John Chommie, William Barker, Victor Thuronyi, Anthony Infanti, Michael Livingston, and Carlo Garbarino. The aim of this article is to develop an intellectual history of comparative tax law. It therefore expands considerably the scholars reviewed and attempts to track their relationships with each other alongside the development of their ideas. 
core" to aspects of tax law. Additionally, the article highlights aspects of these scholars' identities to provide some sense of the people who have taken up this form of tax scholarship. To that end, it is hoped that this article may be of interest to scholars beyond tax law. Part IV offers some concluding reflections on this intellectual history project, drawing attention to the network effects that seem to inform some of the approaches taken by the key contributors to comparative tax law's intellectual history.

\section{METHOD}

A scholar with an interest in comparative tax law has no obvious place to start searching for comparative tax law scholarship. The international tax community does not boast a definitive comparative tax journal. As a result, articles are scattered among general law journals and tax specialist journals. Some tax scholars have authored comparative monographs or edited collections. Searching electronic databases for "comparative tax law" does not yield a comprehensive dataset of articles (and instead yields thousands of false hits), and there are no curated bibliographies or blogs. Older work may not be in searchable format. Library collections are substantially diminished, and obtaining some materials is impossible. As a result, preparing a list of comparative tax scholarship is daunting and any list would inevitably miss contributions. ${ }^{3}$

To complete this project, I systematically built as comprehensive a set of comparative tax law scholarship as feasible over several years. I sorted that scholarship into two broad clusters: work that seeks to advance the discipline of comparative tax law and work that compares tax laws to achieve another objective, without explicit consideration of comparative tax law theory or methods. ${ }^{4}$ This article is concerned with the first strand of scholarship: work that advances the discipline of comparative tax law.

The dataset is bounded, beyond the challenge of work that simply eluded detection or was unavailable through any library system accessed from my home institution. First, with a few limited French exceptions, this article relies on scholarship by academics authored only in English. Second, again with a few exceptions, the history relies on work by academics and ignores work by institutions (like the Organisation for Economic Co-operation and Development (OECD)) or practitioners. The objective of this article is to create an intellectual history and taxonomy for comparative tax law scholarship. While some institutions and practitioners produce work that might be described as scholarship in the sense that it creates new knowledge, the risk of expanding the pool of work is that in many cases the work authored by institutions and practitioners has as its primary purpose providing information to support tax planning or providing descriptive details about other systems for government policy development. Certainly, the former objective (supporting tax planning)

As part of this project, the author has created and maintains a comparative tax law bibliography. It may be obtained by contacting the author.

Even the simple taxonomy suggested in this paragraph is porous. In some cases, the work of a particular scholar, see e.g. Hugh J Ault et al, Comparative Income Taxation: A Structural Analysis (The Hague: Kluwer Law International, 1997), is discussed as a contribution to the work seeking to advance the discipline of comparative tax law scholarship although they do not explicitly engage in a discussion of comparative tax law scholarship. However, given the magnitude of the work and the reliance upon it by subsequent comparative tax law scholars, Ault is identified as a major contributor to the discipline in the first category. 
is not a generally recognized aim for tax scholarship. Additionally, one objective of this article is to support the efforts of tax scholars in the academy who may wish to expand their work in the comparative vein. The work of other scholars provides more realistic illustrations.

Third, again with some modest exceptions, the article focuses on work authored by scholars who find their disciplinary home in law, as opposed to accounting, economics, sociology, or public finance, for example. This decision swims upstream from the more popular view that scholarship should not be cordoned into disciplinary clusters and that instead we might better understand the world if we eschew disciplinary boundaries. ${ }^{5}$ Indeed, one might imagine sustaining the claim that the study of taxation does not have disciplinary boundaries and that knowledge in the area is fundamentally and necessarily interdisciplinary. Nevertheless, part of the peculiarity of law is our attachment to formal legal rules, particularly those expressed in legislation and case law. Study of those rules tends to be unique to legal scholars, located in law faculties, and it is the scholarship that takes those texts as its starting place that is of interest for this article. Perhaps of some surprise, given the press toward interdisciplinarity in many law faculties, few comparative tax law articles by tax law scholars could be described as "interdisciplinary." Many of the authors drew on work produced in economics, in particular, but only a few of them authored work that itself might be described as rooted in the other disciplines, like accounting, economics, sociology, or public finance. Most of the articles were firmly rooted in the conventional legal methods, and most especially in analysis of legislation.

\section{AN INTEllectual History OF COMPARATIVE TAX LAW THEORIES AND METHODS}

As a sign that the discipline of comparative tax law scholarship has been under-theorized, few scholars have explicitly contributed to it. Instead, scholarship that uses a comparative method to approach a particular topic, for example, the tax treatment of corporate losses across jurisdictions, proliferates, largely unguided by connection to a theoretical or methodological literature. The argument of this article, however, is that our national boundedness, combined with the lack of an explicit network of scholars, has masked the rich intellectual and global evolution of comparative tax scholarship. Comparative tax law has an intellectual history, told in this article using the social history of ideas tradition and by embracing the global turn in intellectual history studies. ${ }^{6}$

This part of the article proceeds by conceptualizing comparative tax law's contributions within six phases. The phases are marked by eras that are defined by common approaches to the questions of comparative law.

$5 \quad$ And possibly also runs counter to some of the fundamental tenets of good intellectual history: see e.g. Richard Whatmore, What is Intellectual History? (Cambridge, UK: Polity Press, 2016) ("What marks intellectual history out more than anything else is its interdisciplinary nature. Intellectual historians never respect disciplinary boundaries, except when they are the boundaries imposed by the people whose ideas they study" at 14).

$6 \quad$ See e.g. Samuel Moyn \& Andrew Sartori, eds, Global Intellectual History (New York: Columbia University Press, 2013). 


\section{A. Phase 1: Planting a Flag in the DISCIPLINARY GROUND (1927-1985)}

Phase 1 of the intellectual history of comparative tax law scholarship occurred over an extended period of time. While comparative law burgeoned in the early 1900s, comparative tax law did not gain traction until the period between World War I and World War II. ${ }^{7}$ Early actors in this phase, especially the International Fiscal Association (IFA), were not trying to create a discipline. Instead, they were responding to the pressures on tax advisors to gain knowledge of other countries' tax systems in an increasingly global world.

A flurry of activity commences with John Chommie's contributions later in the phase. Chommie's work develops the notion of comparative tax law as a field of study. Additional contributors - from Canada, Israel, Europe, and the US - offered early, but richly textured, work to the comparative tax law canon. Perhaps not surprisingly, many of them were employed in tax administration or tax practice before commencing their academic careers. For the most part, the scholars in this phase undertook comparative tax law study as a minor strand of their scholarly engagement. While their work resulted in at least some literature that could be taken up by later tax law scholars, very little of it has been cited or obviously relied upon by subsequent scholars. This is a shame because the work in this area is creative and engaging, particularly given the propensity of some of the scholars in this area to explore materials beyond legislation (for example, administrative guidance, court decisions, and, in a few cases, even institutional design issues and interviews with tax actors).

\section{HARRISON SPAULDING}

Harrison Spaulding, a Canadian lawyer, published The Income Tax in Great Britain and the United States, a book based on his doctoral dissertation at the London School of Economics, in $1927 .{ }^{8}$ The book was received to fanfare, and it was reviewed in at least seven major journals, including the Juridical Review, ${ }^{9}$ the Journal of the Royal Institute of International Affairs, ${ }^{10}$ The American Economic Review, ${ }^{11}$ the Journal of the Royal Statistical

Although I found no legal scholars authoring comparative tax law work prior to this era, economist Edwin Seligman's ground-breaking "Progressive Taxation in Theory and Practice" (1894) 9:1-2 Publications American Economic Assoc 1 must be acknowledged as one of the foundational and earliest contributions to the comparative tax literature. Consistent with the general observation that comparative tax scholars do not explicitly acknowledge the contributions of others in the field (through footnotes or mentions within the text of their work), Seligman's work is acknowledged by only about a third of the scholars in this intellectual history, including Spaulding, Thuronyi, Barker, Livingston, Mumford, and Marian.

8 Harrison B Spaulding, The Income Tax in Great Britain and the United States (London: PS King \& Son, 1927).

9 Book Review of The Income Tax in Great Britain and the United States by Harrison B Spaulding, (1927) 39:4 Jurid Rev 469 ("“t]his, so far as we know, is the first comparative study of the income-tax laws of Great Britain and the United States" at 469).

10 RF Harrod, Book Review of The Income Tax in Great Britain and the United States by Harrison B Spaulding, (1927) 6:3 J Royal Institute Intl Affairs 195 ("Mr. Spaulding has produced a clear, workmanlike and stimulating book on a subject which would lend itself easily to the opposite kind of treatment at the hands of one less skilled" at 195).

11 Carl C Plehn, Book Review of The Income Tax in Great Britain and the United States by Harrison B Spaulding, (1928) 18:2 American Economic Rev 324 ("[t]his is a comparative study, accurate, clearly and interestingly written and of value to the layman and expert alike" at 324). 
Society, ${ }^{12}$ The Economic Journal, ${ }^{13}$ and the Journal of the American Statistical Association. ${ }^{14}$ Tax giant Henry Simons reviewed the work in the Journal of Political Economy, although somewhat ambivalently. ${ }^{15}$ Simons claims that Spaulding uses "his three hundred pages to good advantage" and that he has "performed a real service."16 However, Simons also concludes that "[t]he author's ventures into criticism provide the least satisfactory parts of the book."17

Spaulding's work does not offer much by way of explicit examination of its comparative law method. He justifies his comparator jurisdictions (the US and Great Britain) by noting the similarities and differences of their experience with the income tax:

In both Great Britain and the United States, the income tax is the principal source of public revenue, and there is no indication that it will not continue to be so. Great Britain has had the advantage of over a century of experience with it; the United States has had, perhaps, an equal advantage in that it has been free to develop its income tax without the hampering burden of long and firmly established usages. Both countries, since the War, have given close attention to their income tax laws and have made many important changes. ${ }^{18}$

Unlike some of the later extended comparative discussions of income tax law that seek to introduce students to the elements of income taxation, Spaulding clarifies that he has no intention to write a text. Instead, he seeks to identify places where the laws of the US and the UK diverge and to reach conclusions about "the relative merits of each."19 The book is divided into 19 chapters addressing, for example, rates, persons liable, the problem of double taxation, and corporations and shareholders. For each chapter, Spaulding offers some initial comparative reflections on the design of the income tax and then he reviews in more detail the approach taken in Great Britain and then the US on that matter. Spaulding's work is truly comparative: it is focused on identifying and examining the divergences in approach between the two jurisdictions and, ultimately, on taking a view on which approach is better. Noteworthy in the trajectory of comparative tax law, Spaulding looks carefully at the administrative structures of each jurisdiction. Additionally, he is one of the few scholars whose chosen jurisdictions did not include his home jurisdiction. Unfortunately, given its

WHC, Book Review of The Income Tax in Great Britain and the United States by Harrison B Spaulding, (1927) 90:4 J Royal Statistical Society 780 at 780:

Dr. Spaulding has not only attempted, and successfully achieved, [a labourious] study of one Income Tax but of two.... He has deliberately avoided writing a text-book, although this has not prevented him from going into considerable detail in describing the structure of the two laws or from giving appropriate references to numerous legal decisions of importance and other relevant authorities.

13 J Sykes, Book Review of The Income Tax in Great Britain and the United States by Harrison B Spaulding, (1927) 37:148 Economic J 637 (Sykes' review is positive: "the work may profitably be consulted by those who wish for a detailed, comprehensive, and clear account which is supplementary to the general works on public finance, and to the special writings of Professor Seligman and others," although it offers some suggestions for additional topics that would helpfully have been discussed (for example, a chapter on the distribution of the income-tax burden) at 637).

Willford I King, Book Review of The Income Tax in Great Britain and the United States by Harrison B Spaulding, (1927) 22:159 J American Statistical Assoc 408 ("[i]t is rare to find a book dealing with a subject of this kind which is so readable as the present volume. The author displays remarkable ability in extracting the essentials from the laws of the two countries and in making comparisons which bring the important contrasts into relief" at 409).

15 Henry C Simons, Book Review of The Income Tax in Great Britain and the United States by Harrison B Spaulding, (1929) 37:3 J Political Economy 373.

Ibid at 374 .

Ibid.

Spaulding, supra note 8 at 1.

Ibid at 6 . 
thoughtful approach, and surprising given its illustrious reception, reliance on Spaulding's book has been limited and it received scant attention in subsequent comparative tax law studies. $^{20}$

\section{INTERNATIONAL FISCAL ASSOCIATION}

Although anomalous in the selection criteria for this intellectual history, the contribution of the International Fiscal Association (IFA) is acknowledged because of the dearth of comparative tax law academic scholarship in this phase, because of its importance in providing fundamental material that could be used by tax academics and those interested in the comparative law field generally, and because its approach to design is adopted by subsequent tax law scholars. ${ }^{21}$ The IFA has undertaken comparative study as part of its mandate since its formation in 1938. It has published a set of "Cahiers de droit fiscal international" each year since $1947 .^{22}$ The design of the Cahiers has been fixed since the outset. Each Cahier has a specific tax theme; for example, "Taxation with Regard to the Earnings of Limited Companies with International Interests" or "The Territorial Competence of the Fiscal Authorities in the Field of Succession and Property Taxes." ${ }^{23}$ Each Cahier includes a "general report" or general reports, usually authored by one of the world's leading tax practitioners, which builds on the descriptive summaries of substantive law presented by various country reports. These country reports are authored by representatives (again, usually leading tax practitioners but sometimes tax academics) from IFA's branches. This work has been vital to the tax practitioner and tax policy communities. Nevertheless, it has been distinguished from the work of comparative law scholars by Jörg Mössner, who explains that "the purpose of the ... IFA ... congresses [is] really to compare the various tax laws by combining national reports with a general report [and] the result is more a description of the state of national laws than a comparison. ${ }^{, 24}$ In other words, the IFA does not seek to advance

Spaulding's work is not cited by any of the other scholars highlighted in this Part. But see Steven A Bank, Anglo-American Corporate Taxation: Tracing the Common Roots of Divergent Approaches (Cambridge: Cambridge University Press, 2011) at 3-5, 142-43. In his book, Bank seeks to explain why the US and UK corporate tax systems diverged in design. To that end, he takes issue with Spaulding. Spaulding speculates that the countries differed because the entity theory doctrine was more advanced in the US, because the state- and municipal-level taxes on corporations increased US familiarity with corporate-level taxation, and because the US shareholders were seen to be wealthier. Bank's view is that the first two of these explanations overgeneralizes the facts and that the economic power of shareholders was rapidly changing.

21 Competing in the field of work that could be identified as launching comparative tax law as a discipline is the World Tax Series published by Harvard Law School in cooperation with the United Nations. The series' goals were "(1) to describe each country's tax system in its own legal and administrative terms, and (2) to present each system in such a way that it can be compared, point by point, with others": "Tax Reports Published by Law School," The Harvard Crimson (22 April 1957), online: <thecrimson.com/ article/1957/4/22/tax-reports-published-by-law-school/ $>$. The work was not comparative in itself- but it did allow scholars, policy-makers, and practitioners to do comparative work by evaluating how different countries (each country was reviewed in a separate volume) dealt with a common list of issues and problems. The books were authored by leading scholars and practitioners - often with someone in the US (regularly an academic) working collaboratively with scholars and practitioners in the "home" jurisdiction.

22 The first Cahiers were published in 1939, but presumably because of the intervention of World War II, no Cahiers were published between 1939 and 1947.

23. See Cahiers de droit fiscal international, vol 1: "Taxation with Regard to the Earnings of Limited Companies with International Interests" (Rotterdam: International Fiscal Association, 1939); Cahiers de droit fiscal international, t 2, vol 53: "The Territorial Competence of the Fiscal Authorities in the Field of Succession and Property Taxes" (Rotterdam: International Fiscal Association, 1968).

24 Jörg Manfred Mössner, "Why and How to Compare Tax Law" in Claudio Sacchetto \& Marco Barassi, eds, Introduction to Comparative Tax Law (Soveria Mannelli, Italy: Rubbettino, 2008) 13 at 15. 
new insights into tax law, it seeks to better disseminate what is already known and to facilitate knowledge acquisition.

Like the IFA, other international organizations, for example, the OECD, United Nations (UN), International Monetary Fund (IMF), and World Bank have produced rich comparative tax work since early in the twentieth century. Although that research offers much to comparative tax law scholars, it is not further discussed in this article since the framework developed by the IFA sets the stage as the dominant design for future comparative tax law research. While the other international organizations have similarly produced outstanding work, their contributions have not attempted to advance comparative tax law scholarship as an end in itself.

\section{JOHN CHOMMIE}

John C. Chommie, a professor at the Dickinson School of Law (which later merged with Pennsylvania State University) and later a professor at the University of Miami Law School, wrote three short articles in the mid-1950s on comparative taxation and authored a longer intervention in $1960 .{ }^{25}$ In his 1956 piece, Chommie advocated for comparing Canadian and US federal tax law and explained that comparisons of legislative policy-making, administrative process, and judicial process would all be fruitful. Chommie was prescient in noting that valuable comparative work must be something more than the "synoptic description of legal rules and institut[ions]. ${ }^{" 26}$ He pressed scholars to inquire into the social forces affecting policy-making, the role of the executive, and the underlying major policy issues to better understand legislative process in its comparative context. He identified administrative practices as an important element of tax law and suggested that the judicial process might be studied in terms of the machinery of review, the techniques of interpretation, and the notions of judicial function. Ultimately, Chommie's focus in advocating for comparative tax law was to understand the law and context in the countries being compared and to "provide the needed insights for reform in both countries.",27

In 1957, Chommie published an article that advocated for seminars in comparative taxation, continuing his argument that comparative tax law be viewed as a distinct area of tax law study. ${ }^{28}$ Chommie laid out comparative tax law's advantages, which include understanding one's own system better, ${ }^{29}$ assisting in the development of tax theory and tax

See John C Chommie, “A Proposed Seminar in Comparative Taxation” (1957) 9:4 J Leg Educ 502 [Chommie, "A Proposed Seminar"]; John C Chommie, "Surtax Avoidance and Extra Taxation of Corporate Earnings in the United States, United Kingdom, and Canada" (1957) 12:3 Tax L Rev 279 [Chommie, "Surtax Avoidance"]; John C Chommie, "United States and United Kingdom Tax Restraints in Forming, Reorganizing and Liquidating Foreign Corporations" (1960) 2:1 Boston College Industrial \& Commercial L Rev 1 [Chommie, "Tax Restraints"]; John C Chommie, "Why Neglect Comparative Taxation?" (1956) 40:3 Minn L Rev 219 [Chommie, "Why Neglect"].

26 Chommie borrows that language from Max Rheinstein's "Teaching Comparative Law" (1938) 5:4 U

Chicago L Rev 615 at 618, cited in Chommie, "Why Neglect," ibid at 220.

Chommie, "Why Neglect," ibid at 222.

Chommie, "A Proposed Seminar," supra note 25 at 502.

Ibid ("[a]s a condition to understanding other tax systems, one must exhaustively re-examine one's own basic policy position" at 503). 
policy-making ${ }^{30}$ and supporting the needs of a democratic community. ${ }^{31}$ Chommie explicitly advocated for using Canada as a comparator jurisdiction to the US because the language is the same; the materials are readily available; the states are both federal; the countries have similar mixes of agriculture, mining, and other industries; they share a common legal and cultural heritage; and each has been active in developing its tax laws. ${ }^{32}$ One hopes that Chommie was able to offer some comparative law teaching when he served as the Director of the University of Miami's Tax Program or perhaps when he directed a Cuban refugee lawyer program, apparently authoring teaching materials in Spanish to facilitate study. ${ }^{33}$

In 1957 and 1960, Chommie authored pieces that applied his comparative tax law theories. ${ }^{34}$ His 1957 article compared how Canada, the US, and the UK taxed corporate earnings. ${ }^{35}$ Much of the article is consumed with the details of the three countries' approaches, with each country separately discussed, but Chommie's joy in studying tax law in its comparative setting shines through. As he concludes, "[a] study of the tax experience in the United Kingdom and Canada - their formulation and execution of policy — can have an educative and liberating effect on the thinking of tax policy-makers." ${ }^{36}$ The 1960 piece was devoted to the study of how the US and the UK addressed corporate reorganizations. The piece provides little by way of explicit discussion of Chommie's comparative tax law method; however, true to his earlier advocacy, he compares not only the formal legal rules in each jurisdiction, but also their administrative and judicial practices.

Chommie's early work on comparative tax law laid critical ground for the work that was to follow in four ways. First, he stepped beyond the thin understanding of comparative law that imagined only comparing tax laws superficially based on their formal expressions. Second, he articulated some functional and aspirational goals for comparative tax law study: to assist in the development of reforms, to support a better understanding of one's own system, to enrich the theory of tax law and policy-making, and to support a democratic community. Third, methodologically, he specifically and directly addressed his rationale for choosing particular countries as the focus of his study. Finally, in a succinct way, Chommie set out a program of study for tax law comparatists who would follow him. Chommie's 1950s contributions cite no earlier comparative tax work. And, unfortunately, his work has been only scantily relied upon, which suggests that perhaps other scholars did not benefit

Ibid ("it is somewhat fatuous to expect the development of a hitherto neglected sense of public responsibility in the later busy years of practice. Accordingly, thorough training in policy making, at a time when taxation problems can be approached with detachment, would seem to be an essential ingredient of law school courses in taxation").

Ibid ("[t]he development of a usable tax theory consonant with the needs of a democratic community would seem to demand as a prerequisite the articulation and clarification of the values that press for attention in the taxing process" at 504).

Ibid at 504-505.

ME Polen \& JA Thomas, "Inter-American Legal Studies at the University of Miami” (1969) 1:1 Lawyer Americas 42 at 45.

Chommie, "Surtax Avoidance," supra note 25 at 279; Chommie, "Tax Restraints," supra note 25 at 1. Chommie, "Surtax Avoidance," ibid at 279.

Ibid at 296. 
from his insights. ${ }^{37}$ Nevertheless, some of the work that follows seems to have accepted these early insights and to have built from them.

\section{GWYNETH MCGREGOR}

Gwyneth McGregor served as the editor of the Canadian Tax Journal for 18 years, retiring from the editorship in $1970 .^{38}$ She authored 42 articles for the Canadian Tax Journal, alongside hundreds of case comments and editorial notes. ${ }^{39}$ She also served as writer and editor for Canada's Royal Commission on Taxation. ${ }^{40} \mathrm{McGregor}$ was not a tax law academic, but she is included because her tenure at the journal preceded the time when women in Canada were appointed as faculty members at law faculties (a practice that did not begin until the 1960s). One imagines that had the world been a fairer place, she would have made her home teaching and researching tax law in a university setting.

McGregor authored three substantial comparative studies; each compared Canada, the UK, and the US. The first two, both written in 1960, examined employees' deductions and tax appeals, respectively. ${ }^{41}$ McGregor reviews the approach of each of the three countries separately, with a modest introduction and conclusion containing some comparative reflections. Notable, however, is McGregor's broad base of materials - for each country she looks not only at the formal law, but also at administrative guidelines and judicial decisions, and she interviewed tax practitioners and government officials. Her 1962 study, on personal exemptions and deductions, is a substantial contribution. ${ }^{42}$ While each country has a separate chapter, McGregor offers significant comparative analysis and integrates the insights that can be drawn from the individual country studies. Again, she is pluralistic in her choice of materials to support her analysis.

\section{ARYE LAPIDOTH}

Arye Lapidoth was born in 1930 and made significant contributions to tax law and policy in Israel over the course of his career. He served as the Director of Fiscal Legislation at the

For an early citation, see Paul D Lagomarcino, "A Seminar in American and Canadian Tax Law" (1957) 10:1 J Leg Educ 109 at 109, n 1. See also Reuven S Avi-Yonah, Nicola Sartori \& Omri Marian, Global Perspectives on Income Taxation Law (New York: Oxford University Press, 2011) at xvi; Marian, "The Discursive Failure," supra note 2 at 441-43; Stephanie Hunter McMahon, "London Calling: Does the U.K.'s Experience with Individual Taxation Clash with the U.S.'s Expectations?" (2010) 55:1 Saint Louis ULJ 159 at 165-66, n 21. In 1974, Charles Galvin prepared a tribute to John Chommie. That piece does not mention his contributions to comparative tax law. See Charles O Galvin, "Reflection on Tax Reform: A Tribute to John Chommie" (1974) 29:1 U Miami L Rev 21.

38 Neil Brooks, "Canadian Tax Journal: The Second Decade - 1963-1972" (2002) 50:2 Can Tax J 630 at 631 [Brooks, "Canadian Tax Journal"].

Neil Brooks, "Canadian Tax Journal: Fifty Years of Influence" (2002) 50:6 Can Tax J 2059 at 2063-64. Brooks, "Canadian Tax Journal," supra note 38 at 632.

Gwyneth McGregor, "Employees' Deductions under the Income Tax: A Comparative Study of Their Treatment in the United Kingdom, the United States and Canada" (1960) Canadian Tax Foundation Canadian Tax Paper No 21; Gwyneth McGregor, "Tax Appeals: A Study of the Tax Appeal Systems of Canada, the United States and the United Kingdom" (1960) Canadian Tax Foundation Canadian Tax Paper No 22.

42 Gwyneth McGregor, "Personal Exemptions and Deductions under the Income Tax with Special Reference to Canada, the U.S. and the U.K." (1962) Canadian Tax Foundation Canadian Tax Paper No 31. 
Ministry of Justice and became a professor at Bar-Ilan University. ${ }^{43} \mathrm{He}$ pursued a $\mathrm{PhD}$ at the University of London in the 1960s, and his book, Evasion and Avoidance of Income Tax: A Comparative Study of English Law and Israeli Law, was the result of those labours. ${ }^{44}$

Like all work in this era, Lapidoth's study does not offer detailed or lengthy exploration of comparative law theory. Yet, his general approach can be discerned. His choice of jurisdictions was practical — he came from the Israeli system and was studying in London. He notes the similarity of systems, "Israel has retained the income tax law of Palestine; this was basically English Law in a simplified and modified form prepared for the use of British colonies and adapted to the circumstances of Palestine." 45 To the extent that the resolutions to issues are similar, he concludes, "[t]here is no use in comparing" them. ${ }^{46} \mathrm{He}$ also concludes there is no use comparing problems that are too dissimilar. For example, since Israel did not use a trust concept, issues related to trusts were not addressed. ${ }^{47}$ That left Lapidoth to focus on "similar problems which have been differently solved."

Unlike some of the other work in this area, Lapidoth explicitly recognizes tax law's interaction with economics, sociology, and politics, as well as its historical and institutional context. ${ }^{49}$ Like McGregor, he explores legislative, judicial, and administrative expressions of law. He also looks at the institutional design features, like the design of human resource positions in tax agencies. Lapidoth's study is granular and detailed. What it lacks in highlevel reflection and analysis it makes up for by providing rich context, particularly in the case of Israel.

\section{L. HART WRIGHT}

In 1968, L. Hart Wright, then approximately 50 years old, and five additional authors published Comparative Conflict Resolution Procedures in Taxation: An Analytic Comparative Study. ${ }^{50}$ Wright, originally from Oklahoma, joined the University of Michigan as a professor in 1946. Prior to that, he worked for a number of years with the Internal Revenue Service and he served in World War II. He was a regular advisor to the Internal Revenue Service on "matters of organization, training and procedure."

For a brief biography of Lapidoth's wife, see Mika Levy, "Ruth Lapidoth" (27 February 2009) in Jewish Women: A Comprehensive Historical Encyclopedia, online: <jwa.org/encyclopedia/article/lapidothruth>.

A Lapidoth, Evasion and Avoidance of Income Tax: A Comparative Study of English Law and Israeli Law (Jerusalem: Museum of Taxes State Revenue Administration, 1966). For a review, see Stephen Cretney, Book Review of Evasion and Avoidance of Income Tax: A Comparative Study of English Law and Israeli Law by A Lapidoth, (1969) 32:6 Mod L Rev 711 (“"[m]uch of Dr. Lapidoth's thesis is ... based on experience and insight rather than convincing proof ... [h] owever, the book will be of interest to all concerned with revenue law, particularly in countries where a basically English code has to be adapted to new requirements" at 712).

45 Lapidoth, ibid at 14

$46 \quad$ Ibid.

47 Ibid.

48 Ibid [emphasis in original].

49 Ibid at 15-16

L Hart Wright et al, Comparative Conflict Resolution Procedures in Taxation: An Analytic Comparative Study (Ann Arbor: University of Michigan Law School, 1968).

Thomas A Troyer, Arthur B White \& Donald W Bacon, Book Review of Comparative Conflict Resolution Procedures in Taxation: An Analytic Comparative Study by L Hart Wright et al, (1970) 68:8 Mich L Rev 1628 at 1629. 
contributors to the book authored country chapters (on Belgium, France, West Germany, Great Britain, and the Netherlands) in a common format. ${ }^{52}$

The book commences with an explicit discussion of why the volume was written. Importantly, Wright identifies that one of the chief concerns was to provide a glimpse into tax administration practices in developed countries for administrators in developing countries who might be interested in learning more about models that have been developed in places that have had a longer experience with taxation. The countries were chosen because they

differ in their size and population, the complexity and precision of their tax statutes, the degree their legislative bodies provide additional guidance through pre-enactment materials, the assessment system used,

... the standards of construction to which their courts traditionally conform, the theoretical status assigned by each to the doctrine of precedent, and the types of persons available to handle tax disputes. ${ }^{53}$

Additionally, the volume sought to provide tax practitioners with guidance on international approaches to conflict resolution, a purpose which fits easily within this era of comparative tax law. ${ }^{54}$

Part One of the book, which is the only comparative part, analyzes and compares the approach to conflict procedures of the US with the five European countries. Wright uses the country chapters that follow in subsequent parts as the source material for his comparative work. The chapter is densely written and highly detailed. It lays helpful groundwork for tax administrators given that it provides a sophisticated description of the necessary parts for a jurisdiction to develop effective mechanisms for the resolution of tax disputes.

Comparative Conflict Resolution Procedures in Taxation received some attention on publication, with three book reviews. ${ }^{55}$ William Popkin's review in The American Journal of Comparative Law claims that the book "should serve as a model for comparative studies. ${ }^{56}$ He particularly praises Wright for commencing the book with the comparative and analytical chapters, which provide a lens for the reader when they reach the descriptive country chapters. ${ }^{57}$ The most extensive review, in the Michigan Law Review, is offered in two parts. Review I is penned by Thomas A. Troyer, a tax lawyer, and Arthur B. White,

52 Jean Van Houtte, "Belgium"; Pierre Kerlan, "France"; Helmut Debatin, "Germany"; James Arthur Johnstone, "Great Britain"; and H Schuttevaer, "The Netherlands."

Supra note 50 at 3.

Ibid at 4.

Leonard Lazar, Book Review of Comparative Conflict Resolution Procedures in Taxation: An Analytic Comparative Study by L Hart Wright et al, (1969) 18:4 ICLQ 1044 ("[t]his is a competent and interesting work in a field where little research has been attempted and much is needed as the impetus towards tax harmonisation on an international scale increases inevitably" at 1044); William D Popkin, Book Review of Comparative Conflict Resolution Procedures in Taxation: An Analytic Comparative Study by L Hart Wright et al, (1969) 17:1 Am J Comp L 116 at 118:

$[\mathrm{T}]$ here might have been greater orientation towards developing countries if one or two developing

countries, in addition to six western countries, had been chosen for country studies, or if the United

States country study had not been integrated with the analysis.... [T] hese comments might be best considered as an agenda for the future rather than as a criticism of this volume.

Troyer, White \& Bacon, supra note 51 (" [t] he book represents an impressive undertaking, impressively carried out. Professor Wright and his co-authors deserve compliments on a careful, incisive, and thoroughly useful job" at 1636 (Review I); "Professor Wright has charted a course for organizing a system to prevent and resolve [tax law] disputes" at 1638 (Review II)). 
Special Assistant to the Chief Council of the US Internal Revenue Service. They identify the book's audience as "tax practitioners and business advisors ... parties in and out of the Government who wish to refer to the experience of other countries to improve their own tax procedures, and participants in the establishment of new tax structures in emerging nations or elsewhere." 58 Review II is offered by Donald W. Bacon, Assistant Commissioner (Compliance) for the US Internal Revenue Service, who effuses that "[a]ll tax administrators are in his debt." ${ }^{, 59}$ Despite its relative originality (this is the first book by a tax law scholar to rely on the IFA model of individual country chapters as the source material for comparative work; although the comparative work in this book is substantially more detailed and analytical than generally reflected in the IFA reports), as is the case with many authors in this era, Wright's work has not been the subject of much subsequent study by comparative tax law scholars. ${ }^{60}$

\section{MichaEL J. MCINTYRE AND OliVER OldMAN}

In 1975, when Michael McIntyre was starting his career as a professor at Wayne State University and Oliver Oldman was serving as a professor and the Director of the International Tax Program at Harvard University, the two authored Institutionalizing the Process of Tax Reform: A Comparative Analysis. ${ }^{61}$ McIntyre had first met Oldman in 1967, when McIntyre was a first-year student at Harvard Law School and Oliver Oldman taught him in a seminar on tax reform in developing countries. ${ }^{62}$ In the early $1970 \mathrm{~s}$, the two worked together at Harvard's International Tax Program. Their 1975 monograph was the second in the "Selected Monographs on Taxation" series published jointly by the International Bureau of Fiscal Documentation and the Harvard Law School International Tax Program.

The purpose of the monograph was to provide a conceptual framework for evaluating tax reform institutions. The authors review four categories of reform: technical changes in tax law, enactment of tax expenditures, short run changes in rates, and major overhauls. They use multiple countries to illustrate reform techniques, including developing countries (especially Chile, Venezuela, and Colombia). The focus on developing countries is not surprising, given that both authors had connections to the Harvard International Tax Program, which facilitated academic study for foreign officials, teachers, and researchers at Harvard. McIntyre was a newly minted professor when the monograph was released, but his commitment to tax and development continued throughout his career. ${ }^{63} \mathrm{He}$ "served as a consultant to national governments on six continents" and was a tax expert with the UN and OECD. ${ }^{64}$ Presumably he was inspired by Oldman, who was similarly active in consulting with various governments around the world on the development of appropriate tax systems.

Troyer, White \& Bacon, supra note 51 at 1628.

Ibid at 1638 .

See only Victor Thuronyi, Comparative Tax Law (The Hague: Kluwer Law International, 2003) at 206. Michael J McIntyre \& Oliver Oldman, Institutionalizing the Process of Tax Reform: A Comparative Analysis (Amsterdam: International Bureau of Fiscal Documentation, 1975).

William P Alford et al, "In Memoriam: Oliver Oldman” (2009) 122:5 Harv L Rev 1285 at 1292-93.

Perhaps it was inspired by his time in the Peace Corps before law school. See Jaime Arora \& Lee A Sheppard, "Law Professor and Tax Justice Proponent Michael J. McIntyre Dies,” Tax Analysts (2013), online: Citizens for Tax Justice <ctj.org/pdf/michaelmcintyre.pdf>. Ibid. 
As Director of the International Tax Program, Oldman taught hundreds of tax administrators. ${ }^{65}$

It cannot be surprising, then, that the authors show a developed sensitivity to the complexity of comparative tax law research. ${ }^{66}$ They are clear that the type of comparative work they have undertaken requires looking carefully at the context in the compared countries because "[i]nstitutions which appear the same and employ the same names may prove on closer examination to have little in common. Likewise, the common features of institutions are often obscured. ${ }^{, 67}$ Their approach to comparative work reveals a fundamental commitment to the idea that tax systems can, in fact, be compared — as long as "the same type of analytical and descriptive work [is] done concerning the process of tax reform. ${ }^{" 68}$ They set a future agenda for research as requiring a better understanding of the interdepartmental relationships within governments, and they understand the value of obtaining more nuanced understandings of processes from conducting interviews. ${ }^{69}$

\section{B. Phase 2: Major Comparative Tax Projects BY INDIVIDUAL SCHOLARS (1985-1998)}

After a lengthy first phase, where comparative tax law found its foundations - a functionalist commitment and a leaning to doctrinal and conceptual scholarship focused around discrete projects - phase 2 can be distinguished by comparative tax law scholarship comprising major, generally solo, projects by authors with grand comparative aspirations. The format of the IFA work lingers: some of the work in this phase mirrors the structure of country reports preceded or followed by comparative work using the country reports as source material. But a more integrated approach, where an author uses his understanding of the laws of various countries to present a general review of the policy options available in an aspect of tax law emerges as another possible design. Generally, the work of this phase is not self-conscious about its role in advancing comparative tax law - the scholars just do the work, accepting that comparative tax law is a defensible discipline. Additionally, authors in this phase focus primarily on the legislative framework, with less discussion of judicial or administrative guidance, or bureaucratic or institutional practices.

\section{PAUl MCDANIEl AND STANLEy SURREY}

Stanley Surrey and Paul McDaniel were giants in tax policy. Surrey worked in the US Treasury Department before joining the law faculty at the University of California at Berkeley and then at Harvard. He provided international tax policy assistance to a number

William Alford \& Mark Ramseyer, “Oliver Oldman, Expert in International Tax, 1920-2008," Harvard Law Today (9 December 2008), online: < today.law.harvard.edu/oliver-oldman-expert-in-internationaltax-1920-2008/>. Oldman co-authored a major comparative work on the VAT as well. See Alan Schenk \& Oliver Oldman, Value Added Tax: Comparative Approach (Cambridge: Cambridge University Press, 2007).

66 It is surprising that this monograph does not receive greater attention from the later comparative tax law scholars, given its sensitivity to countries' levels of development and its sophistication of analysis. See Richard K Gordon \& Victor Thuronyi, "Tax Legislative Process" in Victor Thuronyi, Tax Law Design and Drafting, vol 1 (Washington, DC: International Monetary Fund, 1996) 1 at 1.

67 McIntyre \& Oldman, supra note 61 at 50 [emphasis in original].

68 Ibid.

Ibid. 
of countries, including as a member of Carl Shoup's famed tax advisory trip to Japan, ${ }^{70}$ and he started Harvard's International Program in Taxation. ${ }^{71}$ Paul McDaniel was a student at Harvard while Surrey taught there; he graduated from Harvard's law school in 1961. He also worked for the US Treasury Department before taking up an academic position at Boston College Law School in 1970. Later, he joined New York University's faculty of law and then University of Florida's law school, and in both cases he was instrumental in the development of the LL.M. in international taxation. ${ }^{72}$

In 1985, shortly following Stanley Surrey's death, Paul McDaniel and Stanley Surrey published an outstanding international review of the tax expenditure concept. ${ }^{73}$ While the book has received significant attention for its contributions to the evolution and understanding of the tax expenditure concept, ${ }^{74}$ it has not usually been referred to for its contribution to comparative tax law scholarship. ${ }^{75}$ The book includes a detailed review of the approach to tax expenditures in Canada, France, the Netherlands, Sweden, the UK, and the US. The editors drew together an expert from each of those jurisdictions and convened group meetings. The work was undertaken over four years.

McDaniel and Surrey were clear in their objectives, which were to develop tax expenditure lists for selected countries using uniform criteria and to make international comparisons of tax expenditures. ${ }^{76}$ They explicitly asked themselves whether the countries' tax histories and philosophies were too different to make comparative study useful, ${ }^{77}$ concluding that comparison was feasible because each country had a concept of a normative income, value-added, or wealth tax that could serve as "a general standard with which to compare the existing tax legislation." 78 They then set out extensive guidelines for how to

W Elliot Brownlee, Eisaku Ide \& Yasunori Fukagai, eds, The Political Economy of Transnational Tax Reform: The Shoup Mission to Japan in Historical Context (New York: Cambridge University Press, 2013).

71 Erwin N Griswold, "In Memoriam: Stanley S. Surrey” (1984) 98:2 Harv L Rev 329 at 329-30. See also William D Andrews, “A Source of Inspiration” (1984) 98:2 Harv L Rev 332.

72 "Prominent UF Tax Law Scholar Paul McDaniel Dies," The Gainsville Sun (17 July 2010), online: $<$ gainesville.com/news/20100717/prominent-uf-tax-law-scholar-paul-mcdaniel-dies>. See also Paul Caron, "Death of Paul McDaniel" (17 July 2010), online (blog): TaxProf Blog <taxprof.typepad. com/taxprof blog/2010/07/death-of-.html>.

73 Paul R McDaniel \& Stanley Surrey, eds, International Aspects of Tax Expenditures: A Comparative Study, vol 5 (Deventer, The Netherlands: Kluwer Law and Taxation, 1985). For reviews of their book, see George E Glos, Book Review of International Aspects of Tax Expenditures: A Comparative Study by Paul R McDaniel \& Stanley S Surrey, eds, (1985) 13:3-4 Intl J Leg Info 106; Aaron Wildavsky, "Keeping Kosher: The Epistemology of Tax Expenditures," Book Review of Tax Expenditures: A Review of the Issues by Committee on Fiscal Affairs; International Aspects of Tax Expenditures: A Comparative Study by Paul R McDaniel \& Stanley S Surrey, eds; Tax Expenditures by Paul R McDaniel \& Stanley S Surrey, (1985) 5:3 J Public Policy 413.

74 See book reviews by Glos, ibid ("'ii]t provides a comprehensive treatment of tax expenditures in the ... six countries on a comparative basis. It is highly recommended for use by tax experts and persons engaging in research in international taxation" at 107); Wildavsky, ibid at 423 :

Despite the high level of the editors' comments (they comprise 118 pages of a 420 -page book, the rest being comprised of lists of tax expenditures in the various countries), their analysis does not justify the claim that this is a comparative analysis of tax expenditures. Such comparison, in my opinion, would require explaining the various ways in which different political forces treat tax preferences.

See only Thuronyi, Comparative Tax Law, supra note 60 at 11, n 36.

See McDaniel \& Surrey, supra note 73 at 5.

Ibid ("[d] espite the differences among countries with respect to forces that have shaped their tax systems - history, social attitudes, culture, jurisprudence, political philosophies, etc. - tax experts from different countries can and do maintain a fruitful dialogue about their respective tax systems"). Ibid. 
identify a tax expenditure in a general way before moving to a country-by-country review of the tax expenditures offered by each country.

Like Wright, McDaniel and Surrey worked backwards into comparativism. The book starts with an extended study of the normative definition of income. Then, supported by discussions with the country experts, the book delineates guidelines for what the benchmark tax system should look like. From that benchmark, deviations that should be considered tax expenditures or tax penalties are identified and the framework is applied to each country's tax systems to produce comparable lists.

\section{PIERRE Di MALTA}

Pierre Di Malta, a tax law professor at the University of Montpellier, published the first solo-authored book in this era claiming to examine comparative tax law in its broad context and to explore the approach to taxation in many jurisdictions. ${ }^{79}$ Di Malta's book (in French) offers material on tax law under three broad headings: taxation of revenue, expenditure, and capital. The book presents detailed information about Belgium, Denmark, France, Germany, Greece, Ireland, Italy, Luxembourg, the Netherlands, Portugal, Spain, and the UK. The parts of the book are organized around the major aspects of tax law design (for example, income from professional activities) with brief statements of the tax treatment of that type of income in each of the jurisdictions. Although the introduction situates the work as important given the need for greater harmonization of European tax systems (and therefore his approach is aligned with comparatist approaches that aspire to harmonization more generally), Di Malta does not offer overarching recommendations about what he views as the best approaches following his study. ${ }^{80}$

\section{VICTOR THURONYI}

Victor Thuronyi's career has included time in tax practice, at the US Treasury Department, and as a faculty member at the State University of New York at Buffalo. In 1991, he joined the IMF's legal department where he served as senior counsel (taxation). Thuronyi published two books that spurred the comparative tax law field. ${ }^{81}$ Capturing the

Pierre Di Malta, Droit fiscal européen comparé (Paris: Press Universitaires de France, 1995). The book has received limited attention from subsequent tax law comparatists. See e.g. Claudio Sacchetto, "Introduction" in Sacchetto \& Barassi, supra note 24, 5 at 10, n 13; Mössner, supra note 24 at 15.

80 Di Malta, ibid.

81 Thuronyi, Tax Law Design and Drafting, vol 1, supra note 66; Victor Thuronyi, ed, Tax Law Design and Drafting, vol 2 (Washington, DC: International Monetary Fund, 1998); Thuronyi, Comparative Tax Law, supra note 60. Every serious scholarly piece on comparative tax law following Thuronyi's 2003 book cites one, or both, of these contributions. For reviews, see John Azzi, "Comparing Income Tax Laws of the World," Book Review of Tax Law Design and Drafting, vol 2, by Victor Thuronyi, ed, (2000) 18:1 BJIL 196 ("Dr. Thuronyi should be commended for his effort and vision in coordinating and producing a valuable book of high quality, which covers a broad range of income tax issues on a comprehensive, comparative basis... Tax Law Design and Drafting (Vol 2) provides a welcome and much needed boost in the ever-growing and increasingly popular study of comparative taxation" at 204); Duncan Bentley, Book Review of Tax Law Design and Drafting by Victor Thuronyi, ed, (1998) 8:1 Revenue LJ 216 ("[t]his is the first of two volumes that any person involved in any aspect of taxation should read.... The two volumes could also form the texts for courses on tax policy and tax design" at 216-17); Tim Edgar, Book Review of Comparative Tax Law by Victor Thuronyi, (2003) 51:6 Can Tax J 2357 ("by combining some of the positive features of existing comparative tax work with the much deeper tradition of comparative legal scholarship, this book breaks important new ground. More particularly, it combines breadth of coverage of country tax systems with a distinct conceptual focus" at 2357); Miranda Stewart, “The "Aha” Experience': Comparative Income Tax Systems," Book Review 
perception that comparative tax law was still nascent as a disciplinary field before Thuronyi's interventions, Tim Edgar stated in his review of Thuronyi's 2003 book, "[i]t is not entirely unfair to suggest that much of the existing comparative work in tax law is of limited interest or even usefulness." ${ }^{82}$ Certainly, Thuronyi's work becomes the "must cite" reference for subsequent tax law comparatists. ${ }^{83}$

Thuronyi's Tax Law Design and Drafting, the first of his books, was published in two volumes, one in 1996 and one in 1998. The edited collection reads as a "who's who" of tax academics, with each chapter focusing on an aspect of tax law design and drafting in a comparative tax law setting. For example, chapter 14, authored by Lee Burns and Richard Krever, examines the design and drafting of the income tax law for individuals and provides a generally applicable overview of the major policy decisions that need to be taken by a country in drafting a personal income tax law. ${ }^{84}$ Specific country examples are provided throughout the chapter, but the chapter is not intended to describe any particular country's personal income tax law. This double volume, which remains the leading source for tax administrators who wish to better understand some of the common elements of tax design and drafting, was motivated by Thuronyi's unabashedly instrumental objective: to assist developing and transition countries in their efforts to reform their systems of taxation.

Thuronyi further and more explicitly develops his theory of comparative tax law in his 2003 book, elegantly titled Comparative Tax Law, ${ }^{85}$ and related articles. ${ }^{86}$ That work reveals aspects of Thuronyi's approach to comparative tax law. He unquestionably loves studying the tax systems of other countries for the joy of learning more about one's own system, as

of The Tax System in Industrialized Countries by Ken Messere, ed; Tax Law Design and Drafting, vol 2, by Victor Thuronyi, ed; Comparative Income Taxation: A Structural Analysis by Hugh J Ault et al, Tax Notes (25 October 1999) 533 [Stewart, "The "Aha' Experience"] (Tax Law Design \& Drafting "is broadly relevant to academics, policymakers, and even practitioners, who may find that the discussion of issues that arise in every income tax can form a useful checklist for structuring transactions or considering potential problems" at 539).

$82 \quad$ Edgar, ibid at 2357.

83 See Marco Barassi, "Conclusions" in Sacchetto \& Barassi, supra note 24, 157 at 161; William B Barker, "Expanding the Study of Comparative Tax Law to Promote Democratic Policy: The Example of the Move to Capital Gains Taxation in Post-Apartheid South Africa" (2005) 109:3 Penn St L Rev 703 at 708, n 27; 719, n 100 [Barker, "Expanding the Study"]; Carlo Garbarino, "An Evolutionary Approach to Comparative Taxation: Methods and Agenda for Research" (2009) 57:3 Am J Comp L 677 at 679, n 5; 705-706, n 65 [Garbarino, "An Evolutionary Approach”]; Carlo Garbarino, "Comparative Taxation and Legal Theory: The Tax Design Case of the Transplant of General Anti-Avoidance Rules" (2010) 11:2 Theor Inq L 765 at 766, n 1 [Garbarino, "Comparative Taxation"]; Michael A Livingston, "Law, Culture, and Anthropology: On the Hopes and Limits of Comparative Tax" (2005) 18:1 Can JL \& Jur 119 at 120 [Livingston, "Law, Culture, and Anthropology"]; Omri Y Marian, "Meaningless Comparisons: Corporate Tax Reform Discourse in the United States" (2012) 32:1 Va Tax Rev 133 at 143, n 29 [Marian, "Meaningless Comparisons"]; Marian, "The Discursive Failure," supra note 2 at 416, n 6; 422, nn 32-34; 443, nn 163-70; 446-47, nn 181-91; 450, n 212; 457, nn 242-46; Paolo Stizza, "International Tax Avoidance and the Abuse of Law in European Union" in Sacchetto \& Barassi, supra note 24,87 at 91 .

Lee Burns \& Richard Krever, "Individual Income Tax" in Thuronyi, Tax Law Design and Drafting, vol 2 , supra note 81 at 495 .

85 Thuronyi, Comparative Tax Law, supra note 60. This book was published in the third phase, and it fits better with the scholarship in that era. However, it seemed more coherent to keep the discussion of a particular author's work confined in one place.

86 Victor Thuronyi, "Why Care about Comparative Tax Law?" Letter to the Editor, Tax Analysts (6 February 1997); Victor Thuronyi, "What Can We Learn from Comparative Tax Law?" Tax Notes (26 April 2004) 459 [Thuronyi, "What Can We Learn”]. See also Alan Schenk, Victor Thuronyi \& Wei Cui for Value Added Tax: A Comparative Approach, 2nd ed (New York: Cambridge University Press, 2015). 
well as about other tax systems $;{ }^{87}$ believes that there are legislative and policy lessons that can be imported and exported from one country to another; ${ }^{88}$ values the explanatory potential of comparing the development of tax laws in different jurisdictions ${ }^{89}$ and expects there to be convergence of legal systems when one resolution to a policy problem is superior to others, taking the position that such convergence is desirable. ${ }^{90}$

One of Thuronyi's novel additions to the literature is the development of legal families for the purposes of comparative tax scholarship. In his 2003 book, he classifies countries into ten families in a rough and ready way, accepting that some countries may belong to a few families. ${ }^{91}$ His claim is that the countries within each family have a common tax law skeleton that should make it possible to predict with some accuracy the tax law design of other countries in the same family once one has familiarity with one of the countries in the family. Even more dramatically, Thuronyi claims that scholars with insufficient time to explore the richer array of families could learn most of what there is to learn from tax law design by studying Germany, the UK, and the US. ${ }^{92}$

Thuronyi's work presents a different methodological model to the one presented by the Cahiers or McDaniel and Surrey. Instead of a descriptive review of each country followed by some comparative reflections, like Di Malta, Thuronyi compares jurisdictions at each stage of his inquiry. His work is organized around the common policy decisions that need to be made in the design of tax law, and different jurisdictions are used to illustrate different legal ways to resolve the underlying policy dilemmas. Thuronyi's approach demands an extensive understanding of the underlying doctrinal or descriptive aspects of each country's legal framework.

As a result of this methodological choice, however, it is probably fair to say that Thuronyi does not focus his work on tax law in its institutional context. While both Tax Law Design and Drafting and Comparative Tax Law provide guidance on the overarching frameworks that guide the reader through the different structural and policy decisions taken in the design of tax law and, to a lesser extent, in the approach to legislative drafting by governments and interpretive matters by judges, the texts do not offer much texture on how the administrative practices (whether in the form of officially issued guidelines, non-judicial dispute resolution, or informal institutional practices) or other economic, social, and political contexts support

Thuronyi, "What Can We Learn," ibid ("[c]omparative tax is therefore not just interesting on its own - because it involves phenomena that are new and different - but causes us to look on our own system with a fresh eye" at 460).

88

See e.g. Thuronyi, "Why Care about Comparative Tax Law?" supra note 86 (“[i]t would be difficult to debate indexing intelligently [in the US] without referring to [how indexing worked in Latin American countries]" at para 2).

89 Thuronyi, "What Can We Learn," supra note 86 ("“c]omparative study allows us to gauge the influence of the past by comparing the development of different countries" at 460).

90 Thuronyi, Comparative Tax Law, supra note 60 ("[ $[\mathrm{t}] \mathrm{his}$ is not to say that the trend has uniformly been in the direction of convergence or that the degree of approximation of tax systems is as great as one would like" at 17); Thuronyi, "What Can We Learn," supra note 86 ("[t]o the extent that tax policymakers behave in a rational way, if there are clearly superior solutions to particular problems, one can expect them to have been adopted by most countries" at 460).

91 Thuronyi, Comparative Tax Law, supra note 60 at 15-44. Between Thuronyi's work on the Tax Law Design and Drafting project, which delineated eight tax families, and his book on Comparative Tax Law, he added Japan/Korea and the European Union as two additional groups to bring the total clusters to ten.

92 Ibid ("three countries (Germany, U.K., and U.S.) will reveal most of the basic contrasts that would arise from including other countries in the study" at 9). 
tax law in the families of countries compared. As Thuronyi acknowledges, one could not expect an author to provide this contextual detail as well as provide the useful and practical overarching framework. ${ }^{93}$

\section{Hugh Ault}

In 1997, Hugh Ault, a tax professor at Boston College Law School, senior advisor for the OECD, and consultant to the UN, published a massive comparative income tax law book, Comparative Income Taxation: A Structural Analysis. ${ }^{94}$ The book is divided into four parts. In Part One, nine tax law professors describe the income tax laws of their home country in a common format. In Parts Two, Three, and Four, Ault provides an integrated comparative review of the law of basic income taxation, the taxation of business organizations, and international taxation.

Ault does not articulate his theory of comparative tax law scholarship, does not offer explicit discussion of his method, and does not acknowledge the contributions of any of the scholars identified so far in this review of the intellectual development of comparative tax law scholarship. However, some elements of his approach are discernable from the general design of the text itself. It is clear that Ault believes that part of the value of comparative tax law is in its ability to reveal aspects of the approach taken in national tax systems that might otherwise have been hidden to insiders. Also apparent is his understanding that comparative tax law is useful as a tool for educating students. Additionally, he sees value from a policy perspective - in terms of the advancement of laws - to looking at the approach adopted by other jurisdictions. Ault provides some justification for the selection of the nine countries subject to comparison: each has a relatively mature and sophisticated tax system and several belong to the same legal family. ${ }^{95}$

See e.g. Thuronyi, Comparative Tax Law, supra note 60 ("I do not emphasize the economic classification, but that is not intended to downplay its importance" at 10).

94 Ault et al, supra note 4 (for reviews, see Alan MacNaughton, Book Review of Comparative Income Taxation: A Structural Analysis by Hugh J Ault et al, (1999) 21:1 J American Tax Assoc 101 ("[f]ew will want to read this book cover to cover. Nevertheless, as a handy reference and a source for short international comparisons of particular issues to put in course readings packages, it is well worth having on the shelf" at 102); Stewart, "The "Aha' Experience," supra note 81 ("[t]he coverage of such a broad array of income tax rules in Comparative Income Taxation means that discussion of each particular issue is of necessity brief, and not every issue is covered" at 537); Hugh J Ault et al, Comparative Income Taxation: A Structural Analysis, 2nd ed (The Hague: Kluwer Law International, 2004); Hugh J Ault et al, Comparative Income Taxation: A Structural Analysis, 3rd ed (The Hague: Kluwer Law International, 2010) (for a review of the third edition, see Michael Livingston, "Recent Developments in Comparative Tax Theory," Book Review of "The Discursive Failure in Comparative Law" by Omri Y Marian; An Evolutionary Approach to Comparative Taxation: Theory, Methods and Agenda for Research by Carlo Garbarino; Comparative Taxation: A Structural Analysis, 3rd ed, by Hugh J Ault et al, Jotwell (7 May 2010), online: <tax.jotwell.com/recent-dvelopments-in-comparative-tax-theory> ("[w]hile the book remains primarily descriptive in nature, any comparativist will tell you that gathering information is half the battle, and much of what is needed, at least for the major OECD countries, is contained here")). Ault had a longstanding interest in comparative law that took about 20 years to bear fruit in his tax publications. See Hugh J Ault \& Mary Ann Glendon, "The Importance of Comparative Law in Legal Education: United States Goals and Methods of Legal Comparison" (1975) 27:4 J Legal Educ 599. But see Hugh J Ault, "International Issues in Corporate Tax Integration" (1978) 10:2 Geo J Intl L 461. Ault et al, supra note 4 at 1 :

The approaches of the United Kingdom, Canada and Australia all display some of the expected degree of similarity, given their common historical roots. The Continental systems likewise, though to a lesser extent, have similarities in structure and result. The United States system has developed without much influence from other systems and the Japanese system has both Continental, especially German, features as well as displaying a strong influence from American ideas in the post-war developments. 
Ault's project is remarkable both in the level of detail provided and in the degree of comparison. Nevertheless, in many areas of Parts Two, Three, and Four, which offer the comparative analysis, the book does not step far beyond recounting in succinct form the approach to each issue adopted by the nine countries presented in the individual country descriptions in Part One. ${ }^{96}$ No effort is made to critically compare legal resolutions to common problems in the jurisdictions; for example, particular approaches are not recommended over others. Still, given its scope and detail, the work has become (along with Thuronyi) a foundation text in the comparative tax law canon. ${ }^{97}$

\section{Phase 3: Reflective Engagement With the Function AND Purpose of Comparison in TAX LAW SCHOLARSHIP (1996-2007)}

Thuronyi's Comparative Tax Law and Ault's Comparative Income Taxation "have achieved such a hallowed status that one could not find a comparative tax article failing to cite them. Yet, both of these texts say almost nothing about the theoretical framework on which they are based. ${ }^{, 98}$ It is responding to the absence of that explicit discussion in phase 2 that inspires the work in phase 3. The work in this era is designed to grapple with what comparative tax law scholarship might entail. There is some overlap in the time periods of phase 2 and 3 work. That is in part because in the period of time between 1993 and 2007, the work in the field was rapidly evolving. But the type of scholarship undertaken can be distinguished. Phase 2 work lacks a self-consciousness about the contribution it is making to the comparative tax scholarship; phase 3 work sets out explicitly to make a contribution not only to the subject matter discussed but also to comparative tax law study more generally. Notably, phase 3 work shifts from a primarily functionalist approach to comparative law to include (in at least some cases) attention to (tax) culture, reflecting the broader debates in comparative law (although lagging behind them). Additionally, contributors are more explicit about the connections between tax law and the underlying private law.

\section{WiLliam B. BARKER}

William B. Barker made both his scholarly and intellectual home in the shadow of Chommie at Dickinson Law, Penn State. ${ }^{99} \mathrm{He}$ also has a standing visiting appointment at the London School of Economics and Political Science. ${ }^{100}$ Among his body of work, he has

As Alan MacNaughton complains, "[t]he book's major weak point is its lack of assistance to readers seeking to pursue issues in greater detail" (Macnaughton, supra note 94 at 102).

97 See Thuronyi, Comparative Tax Law, supra note 60; Marco Adda, "Group Taxation in Europe, Freedom of Establishment and Territoriality Principle" in Sacchetto \& Barassi, supra note 24, 51 at 66; Barker, "Expanding the Study," supra note 83 at 706, n 21; 719, n 100; Garbarino, "An Evolutionary Approach," supra note 83 at 679, n 5; 706, n 67; Garbarino, "Comparative Taxation," supra note 83 at 766, n 1; Livingston, "Law, Culture, and Anthropology," supra note 83 at 120, n 2; Marian, "Meaningless Comparisons," supra note 83 at 198-99, n 241; Marian, "The Discursive Failure," supra note 2 at 416, n 6 and 456, n 236; Mössner, supra note 24 at 24; Sacchetto, supra note 79 at 11.

Marian, "The Discursive Failure," ibid at 416.

Although Barker does not refer to Chommie in his comparative tax law scholarship.

The Pennsylvania State University Dickinson School of Law, "William B Barker Professor of Law," online: <www.personal.psu.edu/faculty/w/b/wbb3/>. 
authored two significant articles that advance comparative tax law scholarship. ${ }^{101}$ Barker's 1996 piece compares the US and UK's tax laws, especially the law of realization and taxable event, in the light of the history of law's evolutions. The article does not set out in great specificity his orientation to comparative tax law; however, the fundamentals of his views are visible.

Barker's approach to comparative tax law is clearer by his 2005 piece, which firmly espouses comparative tax law as a mechanism for "suggest[ing] new directions by removing tax law from the confines of one nation's practice, and by placing it within the wider context of human kind's struggle for greater economic equality". ${ }^{102} \mathrm{He}$ aligns his perspective with those who view comparative tax as a way of assisting the "law-in-action" project, seeking change in legislation and by law's actors. ${ }^{103}$ Eschewing a limited role for comparative tax law as offering only comparisons of formal legal rules, Barker argues for the place of comparative tax law as "a critical advocate for reform, directing its efforts toward the improvement of the lot of people in society. It should be concerned with tax law's role in accomplishing democratic ideals." ${ }^{104}$ Barker accepts the distinction between insider and outsider comparative law scholarship and recognizes that law "include[s] attitudes ... unconscious motivations, [and] frames of reference which rely on special moral judgments." ${ }^{105}$ Nevertheless, he takes the view that, with due study, outsiders can become insiders or at least close enough to insiders to undertake valuable comparative study. ${ }^{106}$

Barker makes two moves in his work that distinguish him from his tax law comparatist predecessors. ${ }^{107}$ First, he recognizes that law is part of a values system and that comparing laws and, more than that, seeking to transplant legal solutions from one country to another, requires uncovering and understanding those underlying values. ${ }^{108}$ Second, Barker acknowledges the role and responsibility of those who interpret law - judges, administrators, private counsellors, and scholars - as key figures in terms of their ability to use comparative tax law to advance the human condition. ${ }^{109}$

\section{ANTHONY INFANTI}

Anthony Infanti, the Buchanan, Ingersoll \& Rooney Faculty Scholar and professor of law at the University of Pittsburgh School of Law, has contributed several articles to the

William B Barker, "A Comparative Approach to Income Tax Law in the United Kingdom and the United States" (1996) 46:1 Cath U L Rev 7 [Barker, “A Comparative Approach”]; Barker, "Expanding the Study," supra note 83 at 703.

102 Barker, "Expanding the Study," ibid at 704.

103 Ibid at 705. See also Barker, "A Comparative Approach," supra note 101 ("superior foreign solutions may be suggested" at 75).

$104 \quad$ Barker, "Expanding the Study," supra note 83 at 708 [footnotes omitted]. I disagree with Marian's characterization that this suggests "little more than that comparative tax is "important"" (Marian, "The Discursive Failure," supra note 2 at 444). Instead, I see this as placing Barker alongside those who see comparative tax law as an avenue to achieve higher-order, aspirational, non-tax values. Barker, "Expanding the Study," ibid at 711 [footnotes omitted] (borrowing from Legrand and Ewald). Ibid at 710. As a consequence of this view, to better situate himself as an insider in his 1996 piece, Barker reviews in detail material about the evolution of the UK's and US's tax systems before he turns to the more concrete project of comparing their approach to realization and taxable events. 
comparative tax law canon. The article that perhaps most contributes to the development of the field as a whole is his 2003 piece, "The Ethics of Tax Cloning." 110 That article takes the claims of the hermeneutics school of thought, which includes as a core principle the impossibility of transplanting the legal ideas of one country to another in the face of sometimes dramatic underlying cultural difference, as a jumping-off point to critique the work of tax reformers from high-income countries who attempt to transplant tax law to lower-income jurisdictions. Stated in its strongest terms, Infanti's analysis is that a missionary zeal

has characterized American efforts to propagate Western legal ideas in developing countries.... The effort to convince these countries of the correctness and universality of our ideas may be perceived either as a benign attempt at sharing with them what has worked for us (fueled, of course, by a healthy dose of American hubris) or as a more malignant, thinly-veiled form of imperialism.... I particularly questioned the utility of replicating all or portions of Western tax systems in the so-called "transition" countries. ${ }^{111}$

Infanti's work adds additional dimensions to the comparative tax literature, including introducing the work of transplant theorists Otto Kahn-Freund and Alan Watson squarely into the tax context and suggesting that legal ethics provides a framework through which tax experts may mediate their engagement in the provision of advice to low-income countries. Ultimately, Infanti does not preclude the possibility of Western advisors assisting with the development or transplant of tax law in transition countries. However, he argues that those advisors need to behave respectfully and in line with ethical standards. ${ }^{112}$

\section{MiCHAEL LiVINGSTON}

Michael Livingston, a tax law professor at Rutgers-Camden School of Law, continues Infanti's emphasis on the importance of culture in predicting similarities between tax laws of different jurisdictions and, presumably, of enabling the transfer of laws from one jurisdiction to another. ${ }^{113}$ Livingston's focus on culture is strategically narrowed to tax

110 Anthony C Infanti, "The Ethics of Tax Cloning”(2003) 6:3 Fla Tax Rev 251 [Infanti, “The Ethics”]. See also Anthony C Infanti, "Decentralizing Family: An Inclusive Proposal for Individual Tax Filing in the United States" [2010] 3 Utah L Rev 605; Anthony C Infanti, "Spontaneous Tax Coordination: On Adopting a Comparative Approach to Reforming the U.S. International Tax Regime" (2002) 35:4 Vand J Transnt'l L 1105. For a recent major contribution, see Anthony C Infanti, Our Selfish Tax Laws: Towards Tax Reform That Mirrors Our Better Selves (Cambridge, Mass: MIT Press, 2018).

111 Infanti, "The Ethics," ibid at 254-55 [footnotes omitted].

112 Infanti's work is referred to in Garbarino, "An Evolutionary Approach," supra note 83 at 679; Garbarino, "Comparative Taxation," supra note 83 at 766; Marian, "Meaningless Comparisons," supra note 83 at 141-42; Marian, "The Discursive Failure," supra note 2 at 440.

113 Livingston, "Law, Culture, and Anthropology," supra note 83 at 119. See also Michael A Livingston, "Convergence, Divergence, and the Limits of Tax Globalization: The Canadian Experience" in Kim Brooks, ed, The Quest for Tax Reform Continues: The Royal Commission on Taxation Fifty Years Later (Toronto: Carswell, 2013) 199; Michael A Livingston, "From Milan to Mumbai, Changing in Tel-Aviv: Reflections of Progressive Taxation and 'Progressive' Politics in a Globalized but Still Local World" (2006) 54:3 Am J Comp L 555 [Livingston, "From Milan to Mumbai”]; Michael A Livingston, "From Mumbai to Shanghai, with a Side Trip to Washington: China, India, and the Future of Progressive Taxation in an Asian-Led World" (2010) 11:2 Theor Inq L 539 [Livingston, "From Mumbai to Shanghai"']. 
culture and, to that end, he does not invoke the broader concerns of the hermeneutics school of thought in comparative law more generally: ${ }^{114}$

What then should scholars do? ... The most promising approach is to carry out studies sufficiently narrow in focus that the interplay of competing forces - national culture, tax culture, the influence of specific institutional structures - can be evaluated without resorting to sweeping generalizations or broad platitudes. Thus, a study of general attitudes toward social justice in the United States and India is likely to be so broad, and so overwhelmed by the remaining differences between the two countries, as to have only limited utility. However, a study of responses to progressive or flat tax proposals in a specific historical period, or the role of particular factors (political, cultural, institutional) in that process may be more rewarding. ${ }^{115}$

This more specific focus, on tax culture as opposed to culture more generally, as part of the explanatory framework for divergences (or similarities) in tax laws explains why Livingston focuses on, for example, the education of tax elites, the relationships between tax professionals, the nature of tax administration, attitudes about compliance and evasion, and the implementation of tax policy in his comparative projects. ${ }^{116}$ Ultimately, Livingston's focus on tax culture, as a local phenomenon, leaves him less convinced that jurisdictions' tax systems will move toward convergence. ${ }^{117}$

\section{ANN MUMFORD}

Ann Mumford, a law faculty member at Queen Mary, University of London, describes herself as someone whose work has "ranged from feminist perspectives on taxation law; to...the integration of tax legal scholarship into the realm of economic sociology." "She has authored two books, which collectively reflect an evolution in the direction of comparative tax law scholarship. ${ }^{119}$ Her 2002 book, Taxing Culture, was undertaken with the aim of "provid[ing] a cultural context for the laws of tax collection, within a comparative, UK/American structure." 120 At a minimum, Mumford attempts to integrate her comparative review of tax law with attention to its cultural context. Nascent in the work, although

Livingston does not refer to the work of any comparative law scholars in his research, so perhaps his reference to culture in his comparative tax scholarship is not intended to connect to any of the more general comparative law schools of thought.

115 Livingston, "Law, Culture, and Anthropology," supra note 83 at 132.

116 Livingston, "From Milan to Mumbai," supra note 113 at 557; Livingston, "From Mumbai to Shanghai," supra note 113 at $552,556$.

117 Livingston's work has been cited in Garbarino, "An Evolutionary Approach," supra note 83 at 679 ; Garbarino, "Comparative Taxation," supra note 83 at 766; Marian, "Meaningless Comparisons," supra note 83 at 144-45; Marian, "The Discursive Failure," supra note 2 at 416-17, 423, 426, 440-42, 448-51, 459-60, 463, 465-66, 470.

118 King's College London, "Professor Ann Mumford," online: $<$ kclpure.kcl.ac.uk/portal/en/persons/annmumford(4473f239-cdce-4236-8750-d39685d16be6)/biography.html>. That Mumford does not explicitly consider herself a tax law comparatist may be part of the explanation for why her work is generally not referred to by contemporary tax law comparatists. But see the following for citations to Mumford's 2002 book only (the 2010 book has not been referred to): Thuronyi, Comparative Tax Law, supra note 60 at 6; Livingston, "Law, Culture, and Anthropology," supra note 83 at 122; Marian, "The Discursive Failure," supra note 2 at 420.

119 See Ann Mumford, "From Dahomey to London to DC: 'Marketing' Wealth with the Proposal for a Comprehensive Inheritance Tax" (2009) 63:1 Tax L Rev 221.

120 Ann Mumford, Taxing Culture: Towards a Theory of Tax Collection Law (Aldershot, UK: Dartmouth, 2002) at 1 [Mumford, Taxing Culture]. For a review, see David Duff, Book Review of Taxing Culture: Towards a Theory of Tax Collection Law by Ann Mumford, (2002) 50:5 Can Tax J 1822 ("[t]hroughout the book, the author adopts a 'critical, cultural approach' to the subject at hand.... Unfortunately, the task of comparative legal and cultural analysis is enormous, and it is often difficult to find the common thread that runs through the various issues that the author chooses to address" at 1823). 
sometimes percolating to the surface, is a more socio-legal and interdisciplinary inquiry into how tax law itself might be integrated into and part of a larger social, political, and economic system that demands interdisciplinary inquiry. ${ }^{121}$

Mumford's approach is further developed by the time she publishes her 2010 book, Tax Policy, Women and the Law: UK and Comparative Perspectives. ${ }^{122}$ Instead of identifying a list of comparator countries, Mumford focuses the work on the UK and draws liberally from the experiences of other countries as she finds it helpful - including from Australia, Bolivia, Canada, Denmark, France, Germany, India, Ireland, Japan, Sweden, Tanzania, and the US. Although tax law remains the focus of the work, its use is instrumental - designed to serve the larger purpose of exploring the link between implicit bias and theories about the status of women in the market economy. ${ }^{123}$

\section{Phase 4: Building a Community of Comparative TAX LAW SCHOLARS (2007-2009)}

Workshops and conferences are markers of the "coming of age" of an academic discipline. After 80 years of scholarship, phase 4 marks the first substantial international academic workshops on comparative tax law. By phase 4, the field of comparative tax law has achieved sufficient profile in academic circles to merit concentrated, collective study. The conferences themselves demonstrate the range of comparative tax law scholarship undertaken by scholars from a wide variety of countries and inspire some scholars who had not previously undertaken comparative work to do so.

In 2007, the University of Bergamo in Italy hosted a seminar on comparative tax law that saw $\mathrm{PhD}$ candidates produce comparative tax law reports as part of a collection that also featured an introduction and two general essays on the directions of comparative tax law. ${ }^{124}$ The work, most of which was written in Italian and translated into English, provides some insight into the approach to the discipline of comparative tax law in Italy, particularly with a view to its setting within the European Union (EU). It reiterates the relative newness of the

121 See e.g. Mumford, Taxing Culture, ibid at 5:

Whether or not the spectre of US-style direct taxation in Europe has strong foundations, placing taxing culture (US, UK, European) in contrast, whatever we draw from it, is interesting. Even on a basic level, it is interesting that one jurisdiction gives tax relief on child care, and another does not. These are matters of formal rules. But it is also interesting that one jurisdiction gives tax relief on child care and has a high proportion of working mothers, and another has the same rule and does not. What this project is attempting to articulate is a means of thinking about a tax culture. Ann Mumford, Tax Policy, Women and the Law: UK and Comparative Perspectives (Cambridge:

Cambridge University Press, 2010).

Ibid at 4:

As indicated by this book's title, comparative perspectives are presented through relational analyses. Different jurisdictions are considered not to determine which affords great equity, but to analyse tax and gender in different contexts, in relation to divergent cultures, legal systems and market structures. The literature and legal structures of the US are considered perhaps most frequently, largely due to the emergence of the interesting and challenging critical tax movement there, although a range of other jurisdictions are addressed as well. The objective of these relational analyses is to forge a link between the issue of implicit bias, and theories as to the resulting status of women in the market economy. 
discipline. ${ }^{125}$ The contributions of Claudio Sacchetto and Marco Barassi, Italian tax professors, and Jörg Mössner, a German tax professor, in the collection reveal a distinct approach to comparative tax law. ${ }^{126}$ First, as with some of the earlier work on comparative law generally, the scholars are committed to the use of comparative law as a means for identifying "better" tax rules and for making better judicial decisions. ${ }^{127}$ They see harmonization as good, at least in the European context. ${ }^{128}$ They embrace the view that comparative tax work should allow a scholar to better understand his or her own system, ${ }^{129}$ and they point to the joy of comparison. ${ }^{130}$ Their three contributions reveal a commitment to moving beyond mere comparison of law "on the books." ${ }^{\text {"131 }}$ They distinguish comparative tax law as a discipline with practices distinct from comparative law, including a unique formant which is defined as "a type of personnel, or a community, institutionally involved in the activity of creating Law." 132 Mössner's chapter lays out a taxonomy of three types of comparative law, borrowed from Ernst Rabel: the applied, the dogmatic, and the philosophical. ${ }^{133}$ His claim is that the work by the IMF reflects the first stage (the applied) and that the comparative tax law work by scholars has brought inquiry into the second stage (the dogmatic), but that what remains is the elaboration of a philosophical approach to comparative tax law scholarship. ${ }^{134}$

The next workshops were hosted by the Monash University Taxation Law and Policy Research Institute, the Israel Science Foundation, the Marc Rich Foundation, and the Institute for Advanced Studies at Tel Aviv University. Following two workshops, the one hosted at the Buchmann Faculty of Law, Tel Aviv University in August 2008 and the second at the Monash University Prato Centre in Italy in June 2009, a collection of essays called

Sacchetto, supra note 79 (" $[\mathrm{t}]$ he study of Comparative Public and Private Law can be regarded as a renowned and well-established tradition. On the other hand, the study of the Comparative Tax Law can be considered, in a certain sense, the new scholar's challenge in the domain of the legal jurisprudence and the Italian Academic Community is taking its first steps, too" at 5).

In Mössner's chapter, the contributions of Di Malta, Thuronyi, and Ault are acknowledged, but not Chommie. Mössner's chapter was authored in 2002, before Thuronyi's 2003 book was released. As of 2002, however, Mössner, supra note 24 at 15, claims

the book of Thuronyi and his co-authors as well as the book of Hugh are without any model. But, having said this, it seems surprising that neither Thuronyi nor Ault deal with the method of comparing tax law. Checking the topics of all seminars of the IFA congresses brings nil return.

This seems the more astonishing as the science of comparative law in general can look back upon a long tradition of methodological disputes about the correct way of comparing law systems. Sacchetto, supra note 79 ("[q]uoting Yasuo Suwa: 'The best way to solve legal questions is drawing comparisons with other countries"” at 6). See also Mössner, supra note 24 at 14.

128 Sacchetto, ibid ("[m]oreover, a comparative study can identify either general or shared rules in order to build up a systematic EU law in Income Taxation domain, better than a EU legislator may do" at 7 [footnote omitted]). See also Barassi, supra note 83 ("typical uses of comparison ... are unification of law and harmonisation" at 164).

129 Sacchetto, ibid (" $[\mathrm{t}]$ he comparative study enables a deeper knowledge of its own law system. In fact, the comparison let scholars detect those implicit elements of their system that are simply verbalized in ... another one. This process allows a better understanding of the domestic law and its evolution" at 8 [footnote omitted]). See also Mössner, supra note 24 at 14. Mössner, ibid ("[i]ndeed, it gives sometimes great intellectual pleasure to compare different tax systems" at 23).

131 Sacchetto, supra note 79 ("scholars cannot confine their search for foreign law in the statute books" at 9). See also Mössner, ibid (Ernst Rabel "stresses that it is not sufficient to compare the articles and paragraphs of a statute, but that it is necessary to evaluate the special article in connection with the whole legal system" at 21); Barassi, supra note 83 ("in comparing one has to look to the law in action and not only to the law in the book" at 159). Pier Giuseppe Monateri, "Methods in Comparative Law: An Intellectual Overview" in Pier Giuseppe Monateri, ed, Methods of Comparative Law (Cheltenham, UK: Edward Elgar, 2012) 7 at 7. Mössner, supra note 24 at 19. 
"Comparative Tax Law and Culture" was published in Theoretical Inquiries in Law. ${ }^{135}$ As the title of the essays makes plain, one of the central questions of the workshop was whether law can transition between cultures. The introduction to the collection promises a focus on interdisciplinary inquiry and an expansion of the subject of study from formal legal rules to formants. $^{136}$

Later in 2009, the University of Michigan Law School hosted a "Conference on Comparative Tax Law in Theory and Practice." 137 Aside from the insights of the various papers that were published in different venues following the workshop, the core efforts of the 2009 Michigan workshop appear to have aimed at two developments. First, workshop participants engaged in discussions about the future agenda for comparative tax law. That agenda was connected, although not exclusively, with a goal to use comparative tax law for practical applications. Second, they connected their discussions directly with the schools of thought developed in comparative law scholarship generally. Those schools were identified, based on Omri Marian's work in particular, as "(1) the functional; (2) the economic; (3) the cultural; and (4) the critical." 138

\section{E. Phase 5: Methodological Contest (2009-2016)}

Until phase 5, tax law comparatists co-existed essentially without contest among themselves. By 2009, the discipline of comparative tax law scholarship had developed to the stage where scholars were, and still are, in contest about methodological approaches and comparative tax law's uses and aims. The two scholars identified in this phase each take quite different positions on comparative tax law, and each has some depth of material to draw from in making his argument.

\section{CARLO GARBARINO}

Carlo Garbarino, a tax law professor at Bocconi University who completed his graduate work at the University of Michigan, published what appears to be the first serious academic article $^{139}$ that attempts to characterize comparative tax law as a field of study connected to comparative legal studies and to build a research agenda using what he terms "comparative

(2010) 11:2 Theor Inq L.

"Introduction" (2010) 11:2 Theor Inq L 469 ("the articles collected here adopt different perspectives regarding the relevant 'social' or 'cultural' factors for analysis - from political struggles, through broad cultural concepts, historical contingencies, administrative and institutional practices, all the way to discrete local actors" at 469).

Reuven S Avi-Yonah et al, "Comparative Tax Law: Theory and Practice" (2010) 64:3 Bull for Intl Taxation 183 at 184 . There was some overlap in participation in the various conferences. The three major players in the Italian seminar did not attend either of the subsequent workshops. Neil Brooks, Tsilly Dagan, Thaddeus Hwong, Kathryn James, Li Jin, Richard Krever, Majorie Kornhauser, Jinyan $\mathrm{Li}$, Yoram Margalioth, and Ajay Mehrotra participated in the workshop that produced the Theoretical Inquiries collection. Reuven Avi-Yonah, Mathias Reimann, Hugh Ault, Victor Thuronyi, Brian Arnold, William Barker, Omri Marian, and Nicola Sartori participated in the Michigan workshop. Only Carlo Garbarino, Assaf Likhovski, and Michael Livingston participated in both workshops.

See Avi-Yonah et al, ibid at 184.

This quickly became a crowded field with the articles produced in response to the various workshops published in quick succession in 2010 and 2011. Garbarino's work has been cited by Marian, "Meaningless Comparisons," supra note 83 (citing Garbarino's 2009 article at 139, n 14 and 145, n 34, and his 2010 article at 139, n 13); Marian, "The Discursive Failure," supra note 2 at 415 (citing Garbarino's 2009 article throughout and 2011 article in working paper form at 438, n 128 and 462, n 270). 
evolutionary analysis." $" 140$ In doing so, Garbarino explicitly embraces the functional approach. ${ }^{141} \mathrm{He}$ advocates for seeing comparative tax law both in terms of the systemic and process elements of taxation and notes that comparison might occur either at a given moment or through a historical lens. ${ }^{142}$

Helping the evolution of the discipline, Garbarino sets out an approach to comparative taxation that requires examining the systemic and process elements of tax systems and then describing how models circulate. ${ }^{143}$ This is a narrower view of the range of objectives of comparative tax law than advocated by many other scholars of comparative tax law. He also proposes a methodology that requires: "(i) selection of methodological approaches; (ii) collection of statutory materials, case law, administrative guidelines, and legal doctrine in the different national tax systems; and (iii) explanation of the data through a coherent functional model."

Building from comparative law scholarship, Garbarino holds the view that there is a tax common core of legal systems that can be discovered through careful comparative study. ${ }^{145}$ This leads him to identify five challenges for building the research agenda for comparative tax law study. ${ }^{146}$ First, to share a theoretical framework that will assist in explaining the process of "competition among tolerably fit tax mechanisms." "147 Second, to study "tax convergence and divergence" with a view to explain tax solutions around the world. ${ }^{148}$ Third, to explain how tax transplants operate. ${ }^{149}$ Fourth, to identify common cores with the aim of constructing an evolutional tax map for EU member states and EU corporate tax law in particular. ${ }^{150}$ Finally, to consider whether there is a tax consolidation model that should be implemented in the EU. ${ }^{151}$

Garbarino believes that by "directly confronting the answers given by local jurists to a set of common questions based on common problems, [and] carefully avoiding explicit linguistic

Garbarino, "An Evolutionary Approach," supra note 83 at 680. Garbarino acknowledges the paper authored by Marian, which was not published until 2010 but had been posted on SSRN (ibid at 679, $\mathrm{n} 5$ ). See Michael Livingston, "Recent Developments in Comparative Tax Theory," supra note 94. See also Garbarino, "Comparative Taxation," supra note 83 at 765; Carlo Garbarino, "Tax Transplants and Circulation of Corporate Tax Models" [2011] 2 Brit Tax Rev 159 [Garbarino, "Tax Transplants"]. Garbarino, "An Evolutionary Approach," supra note 83 at 681; Garbarino, "Tax Transplants," ibid at 159.

142 Garbarino, "An Evolutionary Approach," ibid ("comparative taxation focuses both on the structure (systemic elements) and on the evolution (processes) of tax systems, and it allows their comparison not only synchronically, i.e., in a given moment in time, but also diachronically, i.e., through time" at 683 [emphasis in original]).

a) comparative taxation is based on a comprehensive approach, i.e., a theory of the structure and evolution of tax systems; it looks at how tax systems work dynamically as a whole (tax law-inaction);

b) comparative tax research adopts the functional approach;

c) comparative taxation looks primarily at legal transplants, rather than performing static

comparisons of statutes; and

d) domestic tax change is mainly viewed as the result of circulation of models among countries. Ibid at 685 .

Ibid at 697 .

See also Garbarino, "Tax Transplants," supra note 140 at 184-87 (Garbarino's more specific proposed research agenda for comparative research on the circulation of tax models of corporate taxes).

Garbarino, "An Evolutionary Approach," supra note 83 at 706 [emphasis in original].

Ibid at 707 [emphasis in original].

Ibid at 708 .

Ibid.

Ibid at 709 . 
reference to local tax concepts" one can "decode" local concepts to build a common functional language (the common core) ${ }^{152}$ This belief is connected to his view that comparative tax work is best undertaken using "level-3" language. ${ }^{153}$ Level-3 language is meant to capture the language of tax theory (as opposed to tax legal doctrine (level 2) or statutes, cases, and administrative decisions (level 1)). ${ }^{154}$

Finally, Garbarino contributes in a sustained way to work on tax transplants. ${ }^{155}$ As he articulates, "[a] tax transplant occurs when a tax solution is imported for example from Country C (exporting country) into Country A and Country B (importing countries)." ${ }^{\text {"156 In }}$ his 2011 article, Garbarino offers a taxonomy of transplants that delineates combined tax transplants (which occur when one country receives the tax law of another country but through a different legal vehicle; for example, tax legislation in jurisdiction $\mathrm{A}$ is received by jurisdiction $\mathrm{B}$ in the form of an administrative guideline) and hybrid tax transplants (where there is either a direct, immediate modification or subsequent change to the law received in jurisdiction B from jurisdiction A). ${ }^{157}$ One significant aspect of Garbarino's work on tax transplants is his effort to describe the effect of tax elites on the tax transplant process, an effect that he describes as instrumental to the success and circulation of tax transplants.

\section{OMRI MARIAN}

If Garbarino laid some solid grounding for a comparative tax law research agenda in the twenty-first century, Omri Marian chastised us for taking so long to get to that point. ${ }^{158}$ Marian, who hails from Israel, is a law professor at the University of California, Irvine School of Law. Prior to his appointment there, he held an appointment at the University of Florida, Levin College of Law and he completed his graduate work at the University of Michigan. In his 2010 article, Marian rebukes tax law comparatists for their failure to produce a paradigmatic discourse, to critically engage with each other, ${ }^{159}$ and to build from the comparative law scholarship. ${ }^{160}$ The major contribution of Marian's work is to consolidate some of the insights available from other comparative law and comparative tax law scholarship - insights that were un- or under-recognized by authors of that work. For example, Marian concludes that "“comparative tax law' is not a method of research in its own right, but rather an application of 'comparative law' methodologies to the study of tax laws." 161 According to Marian, the new knowledge created by tax comparatists is knowledge

Garbarino, “Comparative Taxation,” supra note 83 at 772.

Ibid.

Ibid ("[t]he discourse of comparative taxation among tax scholars should use level 3-language to be effective and achieve an acceptable degree of communication" at 770).

Garbarino, "Tax Transplants," supra note 140, is most clearly focused on tax transplants, although Garbarino's theory and taxonomy of tax transplants is laid out in Garbarino, "Comparative Taxation," ibid.

Garbarino, "Tax Transplants," ibid at 171.

Ibid at $171-77$.

Marian, "The Discursive Failure," supra note 2 ("[t]ax comparatists point to the seemingly everprimordial stage of scholarship — a stage from which the field apparently is not able to extract itself" at 416).

In his 2010 article, Marian provides a table that quickly and strikingly reveals how few of the scholars captured by this intellectual history have explicitly relied upon each other's work (by citation). See Marian, "The Discursive Failure," supra note 2 at 425. For a review of this piece, see Michael Livingston, "Recent Developments in Comparative Tax Theory," supra note 94.

Marian, "The Discursive Failure," ibid at 415. See also Marian, "Meaningless Comparisons," supra note 83 at 133.

Marian, "The Discursive Failure," ibid at 421 [emphasis in original]. 
garnered by the juxtaposition of one thing (tax laws) against another that produces observations that could not have been produced in the absence of the comparison. ${ }^{162}$

Marian's work presents a taxonomy of comparative law scholarship. Notably, he classifies comparative law research into four categories: functional, economic, cultural, or critical. ${ }^{163}$ His 2010 article offers a fine introduction to the comparative law literature for tax scholars considering moving toward comparative projects.

Based on the available comparative tax law literature, Marian provides a number of entry points that may lay the foundation for future comparative tax work. He characterizes the work of the leading figures in comparative tax law along the comparative law categories he delineates; ${ }^{164}$ summarizes tax law comparatists' objects of comparison, including the countries chosen, the level of detail employed, and the type of tax law selected; ${ }^{165}$ and offers an overview of the methodological approach of tax law comparatists. ${ }^{166}$ Ultimately, to engage in a dialogue about the sensible approach to comparative tax law, Marian chooses to offer a counter-position to Garbarino. To that end, Marian claims that examining tax laws as "a whole" is an unlikely proposition and postulates instead that deconstructing tax systems into their component parts for analysis may be more fruitful; ${ }^{167}$ he alleges that the form of functionalism to which Garbarino adheres undervalues tax law's important local and political contexts ${ }^{168}$ and he rejects the search for a common core. ${ }^{169}$ Marian ends his 2010 article with a call to comparative tax scholars to better engage with each other with the aim of producing new knowledge that is useful to us. ${ }^{170}$

In his 2012 work, Marian provides a summary of the methodology he then employs in the context of corporate tax reform to achieve competitiveness. Marian suggests that researchers must: (1) determine the purpose of comparison, (2) select the jurisdictions to be compared, (3) select the laws to be compared, and (4) select a methodology of comparison. ${ }^{171}$ Marian does not prioritize one method of comparison over another. Instead, he argues that comparatists "should follow at least some coherent process of comparison and, at each stage, try to absorb the benefits of both comparative methods [functional and cultural approaches] or at least explain why one approach is superior to the other."172

Ibid.

See Marian, "The Discursive Failure," ibid at 426-36. Marian concludes that the economic approach is just a variation of functionalism that centers efficiency. See also Marian, "Meaningless Comparisons," supra note 83 at $138-42$.

Marian, "The Discursive Failure," ibid at 437-45.

Ibid ("[s] ome include numerous jurisdictions in their research in order to encompass a worldwide perspective in their studies, while others find it sufficient to compare only two. Some see tax comparison as a broad issue that necessitates a generalized observation of tax systems as 'wholes,' while others look at narrow issues specifically in order to avoid this generalization" at 445).

Ibid at 454-60.

Ibid at 464.

Ibid at $465-67$.

Ibid at $467-69$

Ibid at 469.

Marian, "Meaningless Comparisons," supra note 83 at 143 . Marian applies this approach to comparison to analyze the use of comparables in US corporate tax reform discourse.

Ibid at 172 . 


\section{F. Phase 6: Reflective Confidence (2017-)}

Two books, published in 2017, reflect the latest phase in comparative tax law's trajectory. These books are reminiscent of the work undertaken in phase 2 and 3, but with new maturity, reflecting the evolution of the discipline. Eduardo Baistrocchi's book reflects a maturity in the IFA model. Assaf Likhovski's work reflects an extension of the approach best previously captured by Anne Mumford's contributions. Each author has affiliations with a middleincome-country home jurisdiction, which also bodes well for the expansion of comparative tax scholarship's reach.

\section{EDUARDO BAISTROCCHI}

Eduardo Baistrocchi, an Associate Professor at the London School of Economics and Political Science (and former Associate Professor of Law at the Universidad Tocuato di Tella in Buenos Aires), edited a massive two-volume book analyzing tax treaty disputes. ${ }^{173}$ The book's chapters are authored by 42 tax academics and practitioners, and they cover 27 countries. The book adopts the IFA format, offering an introduction, country chapters, and four conclusory chapters. It is the conclusory chapters, two of which are written by Baistrocchi, one is co-authored by Baistrocchi (with Martin Hearson), and one is soleauthored by Jinyan Li, that advance comparative tax law. The chapter "Patterns of Tax Treaty Disputes: A Global Taxonomy" illustrates why this book might be seen as advancing the discipline. Instead of simply summarizing the findings of the country chapters, Baistrocchi provides a taxonomy of approaches to tax treaty disputes, identifying 116 patterns in those disputes. Undertaking this work requires painstaking analysis of the country chapters, a willingness to reflect on the insider/outsider status of the author, and a consciousness of the author's theory about comparative law. Baistrocchi employs both quantitative and qualitative methods in undertaking his rich analysis.

\section{ASSAF LIKHOVSKI}

Like Baistrocchi, Assaf Likhovski, a professor of law and legal history at Tel Aviv University Faculty of Law, offers a comparative tax law history project. ${ }^{174}$ His primary focus is to reveal the rise and fall of a socially enforced commitment to paying taxes in Mandatory Palestine and Israel. While tax law itself serves as the focus of much comparative tax law scholarship, Likhovski's work provides a welcome turn (or return) to questions about tax administration, thereby re-expanding the scope of comparative tax law scholarship. The work reflects Likhovski's commitment to comparativism, ${ }^{175}$ although his comparative approach is integrated into the book's design. The book does not have separate sections addressing different jurisdictions. Likhovski adopts a "bottom up" and "top down" approach, looking to an expanded range of data sources for his analysis, including the typical legislative and judicial sources, but thickening that data with cultural reference points like film and

\footnotetext{
173 Eduardo Baistrocchi, ed, A Global Analysis of Tax Treaty Disputes (Cambridge: Cambridge University Press, 2017).

174 Assaf Likhovski, Tax Law and Social Norms in Mandatory Palestine and Israel (Cambridge: Cambridge University Press, 2017).

175 See e.g. Assaf Likhovski, “"Training in Citizenship’: Tax Compliance and Modernity” (2007) 32:3 Law \& Soc Inquiry 665.
} 
literature, including government propaganda material. He holds the view, expounded by several authors in phase 3, that tax law is embedded in a cultural context and as a consequence, local specificity needs to be explored for comparative work to be sufficiently robust.

\section{OBSERVATIONS ON THE TRAJECTORY OF THE Discipline OF COMPARATIVE TAX LAW}

Comparative tax law has an intellectual history in the tradition of the social history of ideas, and it is broadly global in its telling. The story of comparative tax law scholarship begins with pragmatic goals: to offer tax practitioners, and to a lesser extent government policy-makers, a descriptive overview of the tax laws and practices of different jurisdictions. Nevertheless, the early work by Spaulding, Chommie, McGregor, Lapidoth, Wright and McIntyre, and Oldman has surprising usefulness. Their work, under-read and generally excluded from the comparative tax law canon, is worth revisiting. Most distinguishing is the willingness of those early authors to situate their comparative work in its broader frame: to look beyond legislation to the additional insights about tax systems that might be garnered from a comparison of jurisprudence, administrative practices, institutional design, and individual perceptions (captured through interviews). Many of the authors in this period were early in their careers, suggesting perhaps that comparative work was newly of academic interest.

The IFA format - country reviews in a consistent design followed by a general overview report - became the sticking template. It did not inspire work that was especially comparative, although it did enable detailed initial review of the different jurisdictions that might be compared and it led to much greater collaborative work in comparative tax law than in other areas of tax. In some of its thinner forms, the general reports are simply summaries of the country reports. But in their thicker forms, the work of the general reporters provides some basic insights into the underlying structure of aspects of tax systems, with attention to the similarities and divergences in countries' policy responses. ${ }^{176}$ Work from this phase assumes that tax laws in different jurisdictions can be sensibly compared, that little justification for the countries chosen is required, and that tax law has a shared "common core."

As academics became increasingly interested in the potential for comparative work to offer alternative solutions to common tax law design challenges, they began to take on projects on a major scale. The second phase of comparative tax law scholarship therefore saw the publication of lengthy monographs on massive topics - like tax law design, tax expenditures, or income tax law. The IFA format (of descriptive country chapters followed by a summary of overall comparisons) continued, but new approaches - where the work was modelled around the policy questions that government actors need to answer in

176 For a modernized version of the IFA format, see Yariv Brauner \& Pasquale Pistone, eds, BRICS and the Emergence of International Tax Coordination (Amsterdam: IBFD, 2015). In their work, they had scholars from Brazil, China, India, Russia, and South Africa author country description chapters. Those chapters were then provided well in advance to other scholars who were asked to contemplate different international tax policy and design questions using the country chapters as a base. The "general" chapters were not, however, designed to be tied closely to the underlying country chapters, and authors were encouraged to explore a range of additional international tax issues. 
designing tax laws and the discussion of country differences integrated within the analysis itself - emerged. The number of countries being compared proliferated. All of the authors in this phase were distinguished, senior male academics with considerable international advisory experience in addition to their academic interests.

Mirroring trends in legal scholarship more generally, these grand projects were followed by approaches that were more modest in scope (focused on an aspect of tax law), more skeptical (less confident of the value of comparison), or both. The work in phase 3 links comparative tax law with comparative law more generally and in some cases adopts the skepticism of cultural comparatists. Despite the European location of IFA, much, but not all, of the work in phases 2 and 3 was authored by Americans.

By phase 4, comparative tax law had become a mainstream disciplinary topic and a few international workshops inspired scholarly comparative work by authors located in a wider range of jurisdictions. However, despite the purpose of some of the scholarship, which is seen to provide tax law solutions (transplants) to common problems for export/import by lower-income countries, there is no work from scholars in those jurisdictions.

Phase 5 brings new levels of sophistication to the scholarship. Each of the authors in this phase acknowledges at least some of the previous work, takes a stance on their orientation to comparative tax law, and offers critical reflections on the body of scholarship authored to date. Phase 6 offers a reminder of phase 3 - the work is again large-scale, but with the benefit of the intervening contributions, the authors have developed theories of comparative law that support their work.

By way of conclusion, a few observations might be offered about this intellectual history of comparative tax law. First, there are network explanations for the spread of conceptions of the purposes and functions of comparative tax law. There are clear connections among the scholars, which likely explains how some of the ideas they share and develop are transferred, even if their relationships are not apparent through formal citations in their work. Although describing Oliver Oldman, the tribute prepared by Michael McIntyre at Oldman's death reveals the social and intellectual interconnectedness of what is, in at least some ways, a tight community:

He worked closely with some of the leading tax figures of his day. He did tax reform projects with the late economist Richard Musgrave, wrote on tax reform in developing countries with Prof. Emeritus Richard Bird of the University of Toronto.... He gave substance to one of former Treasury Assistant Secretary Surrey's dreams by promoting the World Tax Series volumes on national tax systems. The volume on France, coauthored by Martin Norr, Ollie's longtime associate, won high honors from the French government. Long after his retirement from Harvard, he coauthored a book on the value added tax with my Wayne colleague, Alan Schenk.

During his heyday, Ollie seemed to know everyone, at least everyone in the tax world. A well-traveled friend of mine claims that he could visit almost any developing country in the world and have someone ask about Ollie. I've been to conferences with Ollie at which Ollie introduced me to dozens of people I knew only by reputation. We attended together a memorial service for economist Carl Shoup in a small town in New 
Hampshire, and I think Ollie knew almost everyone in attendance, including some of the members of the large contingent from Japan. ${ }^{177}$

Some of the connections among scholars are likely coincidental; others undoubtedly resulted in the direct influence of scholarly views. For example, Chommie and Barker both taught at Penn State and McIntyre and Wright both taught at Michigan, although in both cases not at the same time. Garbarino and Marian were both graduate students at Michigan. McIntyre, Oldman, and Surrey all had substantial connections with Harvard's International Tax Program. McDaniel and Ault both taught at the Boston College of Law, overlapping there for a period. Infanti completed his LL.M. in Taxation at Boston while McDaniel was teaching.

Second, the disappearance of attention to non-legislative sources for comparative tax work is unfortunate. In some instances, it is understandable: an individual scholar simply does not have the resources to learn about judicial decisions, administrative practices, institutional norms, and individual views for many countries on broad areas of tax law. So, work that attempts to provide an overview of the policy choices reflected in large bodies of legislation is to be excused. Nevertheless, there is presumably much to be learned from the more granular and local specificities of law that are reflected in its other expressions.

Third, at least some of the major comparative tax law work has been inspired by the hope of assisting lower-income countries in the design and development of tax systems. Even though that has been an expressed objective, as noted above, none of the scholars profiled made their homes in lower-income countries. Additionally, with the exception of McIntyre and Oldman, Thuronyi, Infanti, Livingston, and Mumford, most of the work does not use lower-income countries among the comparator set and no scholar uses exclusively lowerincome countries.

Fourth, the vast majority of the authors in the intellectual history are men. Perhaps that is also true of comparative law more generally. If it is the case, perhaps it means that we have drawn the boundaries of comparative law too narrowly, or that the field has failed to attract a diverse range of participants.

\section{CONCLUSION}

To conclude with a reflection about intellectual histories generally, this review of the contributions of tax scholars to the development of comparative tax law provides support for an expansive approach to intellectual history. I share a view with Richard Whatmore, Director of the St Andrews Institute of Intellectual History, that exploring both minor and major figures in the progression of ideas can serve some use. Several of the figures profiled in this review authored their contributions as part of their Ph.D. studies. Additionally, as Whatmore claims, "the fashions of today are themselves the product of accident and unintended consequence. This is one of the most important lessons that intellectual historical research imparts." 178 There does seem to be an element of accident that explains why some 
of the scholars in this review achieved more success (as measured by formal references) with their work than others. It is an impossible exercise to imagine oneself in an era with historical accuracy, and yet in hindsight it seems surprising, for example, that Harrison Spaulding's text, which arrived with significant attention, would have played so little a role in the trajectory of comparative tax law scholarship. In contrast, Hugh Ault's text, which has obtained hallowed status among subsequent comparative tax law scholars, makes a perhaps predictable contribution with less analytical and evaluative content than one might have guessed given the regularity with which it is cited. That notoriety may have more to do with timing, personal reputation, convenience of subsequent citation (in the sense that once a contribution begins to be cited, it then becomes the "Must Cite" reference for others), and other explanatory factors than quality. That may explain why McDaniel and Surrey's review was so important in the development of tax expenditure analysis but has been so little relied upon as an approach to comparative work. ${ }^{179}$ It seems tax law comparatists were not in a position to look for foundational materials until the mid-1990s, and so earlier work - even if it was well crafted and thoughtful - has remained below the radar.

In conclusion, the aspiration of this article is to provide a footing for future comparative tax law work and perhaps even comparative law work more generally. It reveals that comparative tax law has an explainable trajectory, one that reflects the intimacy of the field as well as the limits of engaging in scholarly work without a well-defined dialogue about method. Although scholars in some academic circles question comparative law's future, this intellectual history suggests instead that there are many remaining avenues for fruitful inquiry. As noted above, there is a dearth of literature on the tax landscape of middle- and lower-income countries despite the obvious practical need for more comparative work to support revenue raising. The field has failed to attract a diverse range of authors, suggesting that tax comparatists need to proactively support the development of emerging scholars consider the importance of the work undertaken by $\mathrm{PhD}$ students especially in the early phases of comparative tax's intellectual history. The field could benefit from an expansion of methods. Again, to illustrate by drawing from the first couple of phases, authors were more willing to conduct interviews with tax actors. The rapid expansion of support for empirical research in the legal academy — whether quantitative or qualitative — would be appropriately married with comparative tax law to produce new insights about tax law design and administration. As questions about tax law's evolution and its role in supporting economic and human development become increasing complex, the place of comparative tax scholarship seems increasingly obvious. 